
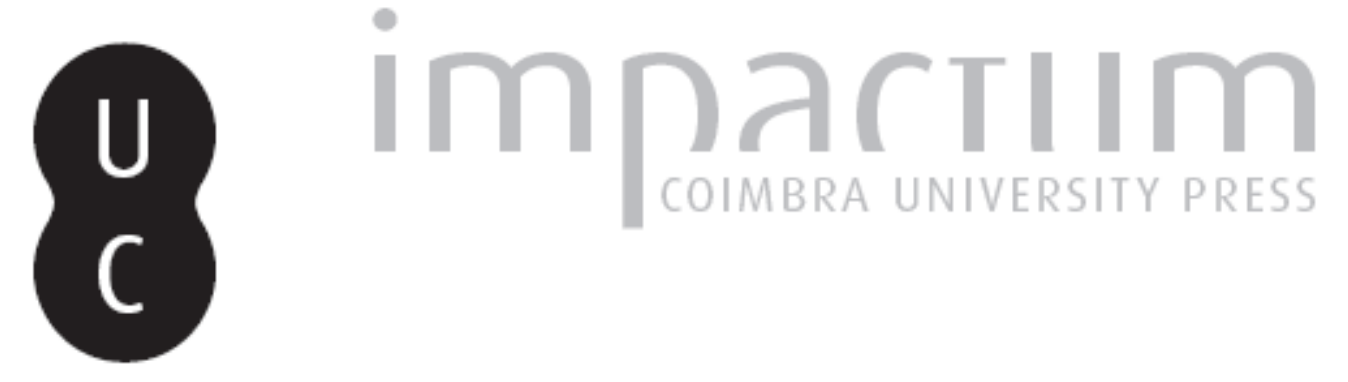

\title{
A exclusão universitária: Sobre o caso Sílvio Lima, 1935
}

Autor(es): $\quad$ Carvalho, Paulo Archer de

Publicado por: Faculdade de Letras da Universidade de Coimbra

URL persistente:

URI:http://hdl.handle.net/10316.2/32411

DOI:

DOI:http://dx.doi.org/10.14195/0870-4112_9_5

Accessed : $\quad$ 26-Apr-2023 11:09:15

A navegação consulta e descarregamento dos títulos inseridos nas Bibliotecas Digitais UC Digitalis, UC Pombalina e UC Impactum, pressupõem a aceitação plena e sem reservas dos Termos e Condições de Uso destas Bibliotecas Digitais, disponíveis em https://digitalis.uc.pt/pt-pt/termos.

Conforme exposto nos referidos Termos e Condições de Uso, o descarregamento de títulos de acesso restrito requer uma licença válida de autorização devendo o utilizador aceder ao(s) documento(s) a partir de um endereço de IP da instituição detentora da supramencionada licença.

Ao utilizador é apenas permitido o descarregamento para uso pessoal, pelo que o emprego do(s) título(s) descarregado(s) para outro fim, designadamente comercial, carece de autorização do respetivo autor ou editor da obra.

Na medida em que todas as obras da UC Digitalis se encontram protegidas pelo Código do Direito de Autor e Direitos Conexos e demais legislação aplicável, toda a cópia, parcial ou total, deste documento, nos casos em que é legalmente admitida, deverá conter ou fazer-se acompanhar por este aviso.

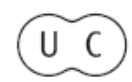



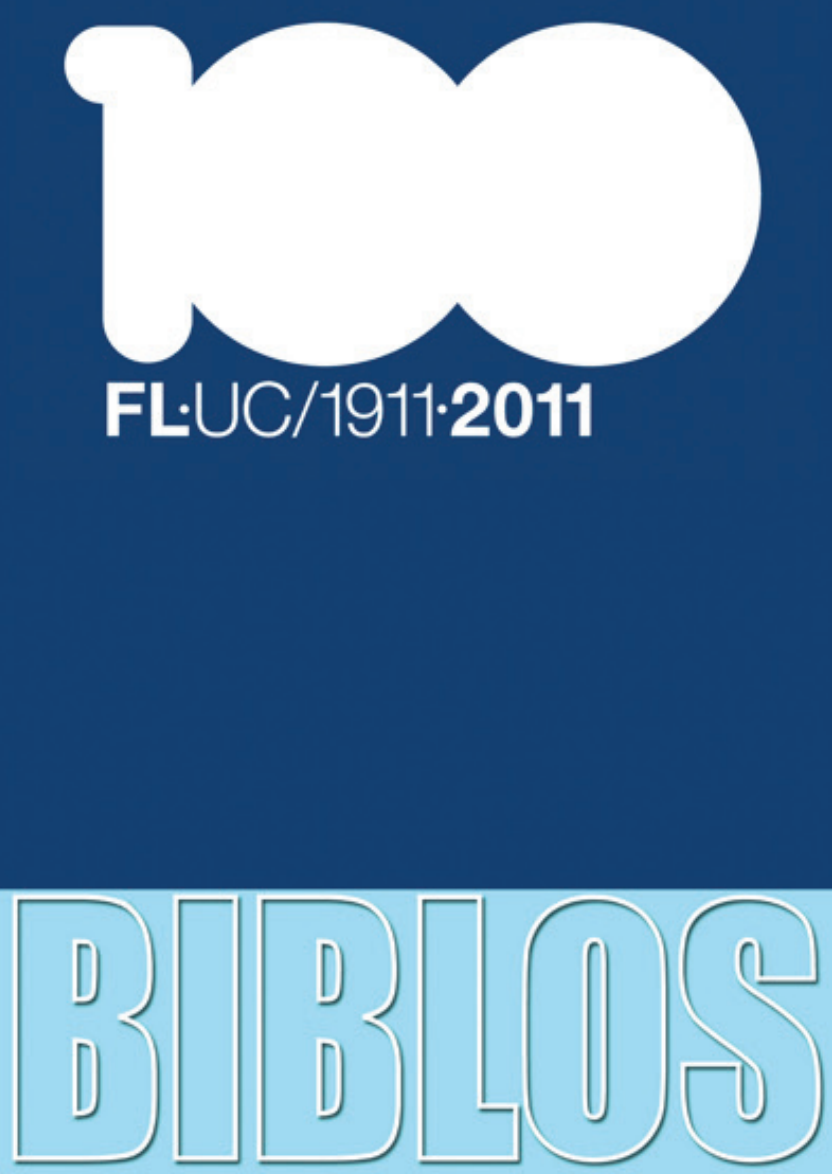

REVISTA DA FACULDADE DE LETRAS UNIVERSIDADE DE COIMBRA 
Paulo Archer de Carvalho*

CEIS2O - UC

\title{
A EXCLUSÃO UNIVERSITÁRIA. SOBRE O CASO SÍLVIO LIMA, 1935**
}

\section{Resumo}

Evidenciar a exclusão universitária, numa «luta de faculdades», como estratégia de eliminação do adversário, e redução da dialogia na universitas é o objectivo do artigo que se insere numa lata investigação sobre aquilo a que o autor denomina «antropologia da exclusão».

Na I parte, «A expulsão administrativa de Deus», estudam-se alguns momentos dessa eliminação - ou dessa tentativa de eliminação ideológica no confronto de mundividências bipolarizadas; na II parte objectiva-se o estudo da expulsão do filósofo e psicólogo Sílvio Lima pelo Estado Novo, integrada na vaga repressiva de 1935 que atingiu alguns dos mais destacados intelectuais universitários portugueses da primeira metade do século XX.

Palavras-Chave: Exclusão, Conflitos religiosos, Secularização e «recristianização» do ensino, Século XX, Teologias da intolerância, Sílvio Lima, Estado Novo, Repressão.

\begin{abstract}
To show how the University exercises exclusion, in the context of a "struggle between faculties," as a strategy to eliminate the opponent and to reduce dialogism in the universitas, is the purpose of this article, which is part of a broader research into what the author calls the "anthropology of exclusion".

In Part I, "God's administrative expulsion," attention is given to some of the moments of that ideological elimination, or of the attempt to do so, in the clash of bipolar worldviews. In Part II the expulsion process of the philosopher

* Bolseiro post doct da FCT.

** Ensaiou-se o texto em «As Gerações de 70 e de 60. Da literatura à política como lutas»», Historicidade, cliOculta, 22-VI-2011, UC, e integra uma mais ampla investigação sobre exclusão universitária.
\end{abstract}


and psychologist Sílvio Lima is studied as part of a repressive wave in 1935 which hit some of the foremost Portuguese intellectuals at the university during the first half of the $20^{\text {th }}$ century.

Keywords: Exclusion, Religious conflicts, Secularization and "re-Christianization" of education, 20th century, Theologies of intolerance, Sílvio Lima, Estado Novo (Second Republic), Repression. 


\section{A expulsão adiminstrativa de Deus}

Em 1907 a greve estudantil contra o foro académico, pela secularização, modernização e liberdade do ensino - cursos livres e universidades livres, em contraditas versões difundem-se na Europa desde o séc. XIX -, anuncia a mutação do paradigma. Em março de 1911, abolindo o velho monopólio, a República cria as Universidades em Lisboa e Porto ${ }^{1}$, ante o conservadorismo coimbrão que teme o colapso das Escolas e o radical apoio estudantil (Falange demagógica, Enterro da Cabra) que incita ritmos e metas das reformas ${ }^{2}$. O republicanismo laiciza o paradigma simbólico e a paideia cívica ${ }^{3}$, "porque a grande razão política das revoluções incide nas transformações sociais que estas importam" e tal como "a Revolução Francesa destruiu as instituições de ensino herdadas da sociedade católica" criando "sob inspiração dos enciclopedistas e dos convencionais novos organismos pedagógicos", assim a "Revolução Portuguesa de 5 de Outubro tem o dever de reformar os diversos ramos do ensino para chamar a Nação ao exercício da democracia", tornando a instrução básica obrigatória e gratuita, formando dirigentes através da reforma do ensino superior e reformando o ensino médio e técnico em vista ao funcionalismo e profissões liberais ${ }^{4}$. Banidos signos e juramentos religiosos, "atendendo que as ciências entraram definitivamente no período de emancipação de todos os elementos estranhos à razão"5, o obrigatório uso discente da batina, reminiscência do hábito talar, caía com o culto na capela privativa ${ }^{6}$. A Constituição universitária (depois debatida na Constituinte, onde o

${ }^{1}$ Lei de 22 de março, Diário do Governo, nº 68, de 24 de Março de 1911.

${ }^{2}$ Cf. Fernando Correia, Vida Errada. O romance de Coimbra, C. ${ }^{a}$, Coimbra Editora, 1933, 137-57.

${ }^{3}$ Consonante com a interdição do hábito talar e abolição de juramentos religiosos (8-X-1910), do ensino religioso (18-X-1910), a extinção de Direito Eclesiástico, é a legislação da família e do divórcio (3-XI-1910).

${ }^{4}$ Preâmbulo do dec.-lei de 22-II-1911, Ensino Médico; compilação in Anuário da Universidade de Coimbra, 1910-1911, Coimbra, Imprensa da Universidade (IU), 1911, 265-66.

5 Ibidem, preâmbulo, 263.

${ }^{6}$ Decreto com força de lei de 21-I-1911, apud ib., 262-63. 
lobby coimbrão trava a extinção da velha Universidade ${ }^{7}$ ), augurando a Lei da Separação ${ }^{8}$, a protoconstituição de 1911 , criando em Coimbra a Faculdade de Ciências e a Escola de Farmácia, ratifica a extinção da Faculdade de Teologia.

A liquidação do foro académico, a 23 de outubro de 1910, atendia à longa revindicação das lutas estudantis progressistas desde 1854-64. Não admira que sectores tradicionalistas não atendessem ao distúrbio semântico entre foro e Polícia Académica: para estudantes e o legislador republicano 9 eram sinónimos. Nesse dia, declarando "livres os cursos de todas as cadeiras", extinguiu-se o toque da cabra símbolo do controlo jurisdicional da autoridade académica (a geração de 1864 roubara o cabrão) e reminiscência eclesiástica do tempo universitário (presença, dispensa, recolhimento) ${ }^{10}$ na cidade dos colégios e dos sinos. Uma festividade académica, o enterro da cabra no Largo da Feira a 17 de novembro de 1910, soleniza o fim de um tempo (que não findara). Por outros e para outros os sinos ainda iriam dobrar. Se a luta contra a Polícia Académica fora ganha, a rebelião estudantil contra métodos repressivos policiais não cessa: em Maio de 1913, 39 alunos (Alfredo Fernandes Martins, o da Bastilha, e João do Amaral, depois integralista) são inculpados e presos nos violentos motins, com tiroteio, pugilato e dezenas de feridos na Alta. A autodemissão do reitor Mendes dos Remédios, recusando que alunos sejam examinados em Lisboa como

${ }^{7}$ Cf. Rómulo de Carvalho, História do ensino em Portugal, Lisboa, Gulbenkian, 1986, 688. J. Madureira, A Forja da Lei. A Assembleia Constituinte em notas a lápis, Lisboa, Assembleia da República, ${ }^{2 \mathrm{a}} 2011, f-s, 249-255$.

${ }^{8}$ A Lei da Separação de 20 de abril (Diário do Governo, n. ${ }^{\circ}$ 92, 21-IV-1911) precedida pelo decreto de $8-\mathrm{X}\left(D G, \mathrm{n} .^{\circ} 4,10-\mathrm{X}-1910\right)$, repunha em vigor as leis de 3-IX-1759, 18-VIII-1767 e 28-V-1834 que expulsaram os Jesuítas "por desnaturalizados e proscritos" e extinguiram as ordens religiosas: "a religião católica deixa de ser a religião do Estado" $\left(\operatorname{art}^{\circ} 2^{\circ}\right)$, pois a República "não reconhece, não sustenta, nem subsidia culto algum", suprimindo despesas públicas com o culto $\left(\operatorname{art}^{\circ} 4^{\circ}\right)$ e ensino religioso, regulando administrativamente os cultos.

9 Decreto-lei de 23-X-1910, apud Anuário(.) 1910-1911, o. c., 251-52, e dec. de 23-X-1910,ib., 253.

${ }^{10}$ Ana Cristina Araújo, «As horas e os dias da Universidade», Universidade( $s$ ), Actas 3, C. ${ }^{\text {a }, ~ U C, ~ 1991, ~ 365-81 . ~}$ 
o governo determinara, é indício concreto (e a sequela) da perdida auctoritas penal e corporativa dos prelados universitários ${ }^{11}$.

\section{Expulsão da Teologia em 1910 e a criação da Faculdade de Letras}

A Universidade permaneceu até 1910 (reforçada na sua simbologia em 1901) em grande parte uma universidade Católica e daí a República secularizar o programa cívico e demopédico que os seus teóricos há muito propugnavam $^{12}$. A expulsão de Deus, é o mais claro sintagma modernizador nos ritos e símbolos universitários. A extinção da Faculdade de Teologia, correlata do longo declínio dos estudos jurídico-eclesiásticos, era por ela sugerida e discutida. Lente de Hermenêutica Sagrada, Mota Veiga admitia a escassa frequência, "os poderes públicos não oferecem nem dão aos estudantes teólogos garantias algumas eficazes para os atrair ao estudo da ciência da religião", razão pela qual "os alunos vão sempre escasseando mais nas aulas de Teologia" pois a licenciatura jurídica, desleal concorrente, conferia em plano de igualdade o acesso e o provimento aos lugares eclesiásticos ${ }^{13}$.

O fim da Teologia era exigido por adversos campos. Republicanos, livre-pensadores, mações, para quem a dimensão autotélica da liberdade só faria sentido numa sociedade secularizada e na Escola laica, exprobravam o ensino confessional e remetiam o estudo das religiões para o quadro das ciências históricas e sociológicas. Teólogos, como modo prático de assegurar cátedras perante as bancadas vazias, propunham a sua desagregação e a criação da nova Faculdade, designada de Letras (na linha francesa das iniciais propostas), onde estudos teosóficos, porventura teológicos e de história das religiões, pudessem noutras

${ }^{11}$ António Sousa Lamy, A Academia de Coimbra. 1537-1990, Lisboa, Rei dos Livros, 1990, 196-201; Francisco MoraIs, Reitores da Universidade de Coimbra, Coimbra, Imprensa de Coimbra, 1951, 100-01.

${ }^{12} \mathrm{Cf}$. Fernando Catroga, «A Universidade portuguesa e as Universidades europeias», AAVV, História da Universidade em Portugal, vol. II, (2009, provas), 3-72. Cf. P. ARCHER, Sílvio Lima. Um místico da razão crítica (Da incondicionalidade do Amor Intellectualis), Coimbra, pol. FLUC, 2009, liv. I, cap. I, 1-37.

${ }^{13} \mathrm{M}$. DA MotTa Veiga, Esboço Histórico-Litterario da Faculdade de Theologia, Coimbra, IU, 1872, 305-07. 
vestes sobreviver ${ }^{14}$. Condizia com o velho projecto $^{15}$ de emancipação dos estudos humanísticos - confinados, nos Estatutos de 1772, ao âmbito dos «estudos menores» aí assegurados pelo Colégio das Artes $^{16}$ - que sectores regeneradores anunciavam, mormente nos debuxos legislativos dos lentes José Maria de Abreu (1857) e António José Teixeira (1874), deputados à Assembleia legislativa, que não vingaram, apesar do primeiro, em Claustro pleno de 10 de abril de 1867, originar a representação decidida a fundar a Faculdade de Letras ${ }^{17}$. Em seu lugar, convergente com a autonomia epistémica e curricular dos saberes históricos, filosóficos e filológicos nas mais avançadas universidades europeias e a crescente utilidade pública na preparação específica do magistério liceal, mais do que à propedêutica universitária inicialmente ideada $^{18}$, vencera o plano, em 1858, da criação dos Cursos Superiores de Letras em Lisboa e Coimbra, que só na capital, sub tutela da Academia das Ciências, vigoraria a partir de 14 de Janeiro de $1861^{19}$. Extinto o Colégio das Artes (1548-1836), Coimbra e Universidade degradaram a tradição do ensino de Humanidades que no séc. XIII a Faculdade das Artes ministrara, depreciação cujos sintomas se traduziam na minoração da história ao arquétipo cronístico, à narrativa apologética e hagiográfica e o claro desinteresse pelos estudos filosóficos subalternizados pelas ciências jurídicas.

${ }^{14}$ Catroga, $O$ republicanismo em Portugal da formação ao 5 de Outubro de 1910, C. a, FL, 1991, II, 403.

${ }^{15}$ Cf. o plano de Luís Mouzinho de Albuquerque (1823), e Rebelo de Carvalho, da criação de Academias (Lisboa, Porto, Coimbra) com Faculdades de Letras. Retomado, em 1835-36, por Dias Pegado e Figueiredo e Almeida, não vingaria J. Ferreira Gomes, «Dois projectos de lei do século XIX (.)», Biblos, LX, 1984, 520 e ss.

${ }^{16}$ No preâmbulo da proposta de criação da Faculdade de Letras em 1854 regista-se que esta visara, no âmbito da reforma Pombalina, substituir o Colégio das Artes, o que não se objectivou nos Estatutos de 1772 - J. FerreIra Gomes, «Dois projectos de lei do século XIX ...», o. c., 523.

${ }^{17}$ A. DE VAsConcelos, «Alocução», Acta de 22-XII-1919, A Universidade de Coimbra no século XX. Actas da Faculdade de Letras, vol. I, (1911-1925), Coimbra, Pub. do AUC, 1989, 171.

${ }^{18}$ Sérgio CAmpos Matos, «O Curso Superior de Letras e a vulgarização histórica em Portugal: dois projectos em confronto (1858-1901)», Actas 1, o. c., 369-70.

${ }^{19} C f$. J. Ferreira Gomes, «Dois projectos de lei...», o. c., 522-24 e 540. 
Resposta tardia ao não instalado Curso de Letras e a novas exigências que em meados do século da história se evidenciam, mormente na Faculdade de Direito, dado o maior peso da perspectiva histórica e filosófica dos estudos jurídicos ${ }^{20}$, a criação da Faculdade de Letras passou por óbices que a adiaram para as calendas, conquanto seja exigida em 1880, em Claustro pleno de 16 de abril (Manuel Emídio Garcia e Augusto Filipe Simões) no Centenário de Camões ${ }^{21}$. Objectivava-a a pugna, após 1885, entre os regalistas teólogos da Universidade e o bispo de Coimbra, Bastos Pina, que contesta a precedência do Estado sobre a Igreja no ensino teológico, ligada à obtenção obrigatória do grau respectivo na Faculdade para o ingresso em benefícios e cargos eclesiásticos. A pretensão dos lentes levaria à censura episcopal das obras dos contestatários ${ }^{22}$ (Damásio Fragoso, José Maria Rodrigues, Araújo e Gama), postos no Index, quando na literatura teológica se faz sentir a orientação neotomista da Cúria. Em sequência, o reitor Adriano Cardoso Machado, a 1 de outubro de 1888, anuncia a iminente criação da Faculdade mas só em 1907, vinte anos depois, os cinco conselhos facultativos criam consenso na comissão (cujo delegado de Teologia era Mendes dos Remédios ${ }^{23}$, desiderato de novo gorado. Só a República o fará no âmbito da reforma do ensino superior consubstanciada na lei de bases, a Constituição Universitária ${ }^{24}$. Mas persistem óbices decorrentes do espaço físico próprio que individuasse o novo saber humanístico do magistério teológico e que dispusesse dos recursos didácticos

${ }^{20}$ J. Frederico Larano, Conveniência duma Escola de Philosophia anexa à Universidade, Coimbra, Imprensa Literaria, 1864; M. EmíDIO GARCIA, «Importância dos Estudos Históricos nas Sciencias Jurídico Sociais e o Ensino da História em Portugal», O Instituto, n. ${ }^{\circ}$ 19, 145 ss.; $c f$. F. CATroga, «O sociologismo jurídico em Portugal e as suas incidências curriculares (1837-1911)», Actas 1, o. c., 404-05.

${ }^{21}$ ANTÓNIO de V AsConcelos, «Alocução» apud o. c., 171-72.

${ }^{22}$ J. M. CRuz Pontes, «Para a história da Faculdade de Teologia no século XIX: beneplácito régio contra a autonomia do ensino», Actas 1, o. c., 332-33. Se a legislação de 1877 (dec. de 26-IV) indirectamente favorecia a frequência dos seminários diocesanos em detrimento da Faculdade; a paridade com a licenciatura em Direito anulava o interesse pela licenciatura teológica.

${ }^{23}$ A. VAsConcelos, «A Faculdade de Letras», Rev. da Univ. de Coimbra, vol. I, t. IV, 1912, 629-30.

${ }^{24}$ J. FERrEIRA GOMES, «A Reforma Universitária de 1911», Revista de História das Ideias, 12, 1990, 272. 
adequados a receber os muitos alunos esperados, em troca da pequena turma que se perdia.

A crise da Teologia desde 1836 vincula o signo secularizador do Liberalismo, ao contrariar a minoração dos estudos filosóficos post reforma de 1772, não autonomizada do quadro jurídico, nem da Filosofia Racional e Moral das ciências naturais (História Natural; Física Experimental; Química). Acompanha a estagnação dos estudos jurídico-eclesiásticos e o «percurso secularizador» objectivado em 1836 na extinção da Faculdade de Cânones ${ }^{25}$ e a minoração do Direito eclesiástico e canónico nos planos curriculares das reformas de 1844 e 1865, correlatos da crescente sociologização dos saberes jurídicos ${ }^{26}$, plasmada na reforma Hintze Ribeiro (1901) asilando $o$ "espraiar da vaga do naturalismo e do positivismo" 27 . Mas a produção teológica tornou-se paradoxalmente mais especulativa, desde 1860-70: teólogos cerram $\mathrm{o}$ ataque a racionalismo, idealismo ecléctico de matriz kantiana, materialismo e positivismo, ancorando a crise da Filosofia, exaurida em breve por ataques cientistas, como sequela descristianizadora sentida no campo dos intelectuais ${ }^{28}$. Para o lente Silva Ramos, consonante com os pares, a cisão entre filosofia e teologia teria sido "a fonte de todos os erros do espírito humano" 29 .

${ }^{25}$ De Cânones resistiam duas cadeiras em Direito: História da Jurisprudência em geral (predominava o Direito Romano) e Instituições de Direito Eclesiástico (desdobrada em 1844 e 1865). Direito Eclesiástico seria extinto na República por proposta do vice-reitor Sidónio Pais (XI-1910). Como evidenciou Paulo Merêa, desde 1836 com o abandono de temas eclesiásticos nas teses doutorais, dá-se o desinteresse científico e prático das matérias. Na véspera da República, Marnoco e Sousa, último titular de $D .{ }^{\text {to }}$ Eclesiástico, instava em o ministrar na perspectiva aconfessional. Cf. Jõ̃o Luís Oliva, O domínio dos Césares, Lisboa, Colibri, 1998, $31 ; 75-85$.

${ }^{26} \mathrm{Cf}$. Fernando Catroga, «O Sociologismo Jurídico em Portugal...», Actas 1, o. c., 399-414.

${ }^{27}$ L. CabRal de Moncada, Subsídios para uma História da Filosofia do Direito em Portugal (1772-1911); J. L. Oliva, O domínio dos Césares, o. c., 65.

${ }^{28} \mathrm{C} f$. Maria Fernanda Figueira, A Faculdade de Teologia e o «Racionalismo» do século XIX, Coimbra, FLUC, tese de lic. em Filosofia, pol., 1970; e id. «A Faculdade de Teologia perante o Materialismo (1861-1905)», Revista de História das Ideias, 1, 1976, 205-35.

${ }^{29}$ Luís Da Silva Ramos, Dignidade da Razão perante a Fé, Coimbra, 1873, 33-34; M. ${ }^{a}$ Fernanda Figueira, A Faculdade de Teologia e o «Racionalismo» do século XIX, o. c., 368-69. 
Ora, o fim da Teologia não significou a expulsão física dos mestres. Ex-teólogos criam mesmo a autêntica matriz qualitativa da Faculdade de Letras pois desde finais do séc. XIX orientam ensino e investigação no sentido da historiografia, filologia, literatura e pedagogia ${ }^{30}$, colhendo a visão civilista que fundamenta o paradigma positivista, cientista e laico dos estudos humanísticos que a República promove, ministrando-o porém numa lógica conservadora ${ }^{31}$ que expede para a gnose religiosa ${ }^{32}$. Em 1919 admitiam os ex-teólogos ${ }^{33}$. que "nos últimos anos do antigo regime, a frequência da Faculdade de Teologia diminuíra dia a dia progressivamente", por, entre outras razões, ser "demasiadamente secular" e se achar "de mal com os Bispos por causa do Estado" e "de mal com o Estado por causa dos Bispos", motivo que levara a Faculdade ela mesmo a pedir extinção. Se em 1878 havia 44 matrículas, em 1909-10, para 12 professores (10 catedráticos e 2 auxiliares), alguns ausentes em comissão de serviço ou noutras funções, apenas havia 20 alunos: seis no I ano (dos quais Cerejeira), um no II, três no III, quatro no IV e seis no V. Toda a Faculdade não enchia a menor sala ${ }^{34}$.

Erro estratégico na lógica da escola fora a sua extinção, escreve Joaquim de Carvalho em 1931, pois "os estudos teológicos embora involuam entre nós jamais cessaram e se forçou o clero a ilustrar-se em escolas teológicas do estrangeiro" 35 , onde, na tradição alemã ou meridional avançam. Diga-se que a liquidação da Teologia condicionou a contrario os discursos secularizadores dos saberes humanísticos, alastrando em abusivos planos, currículos, conteúdos e grelhas geridos na Faculdade de Letras, vigiados pelo ampliado clima de repressão filosófica que o Estado Novo assacou às universidades portuguesas.

${ }^{30}$ Cf. P. Archer, Sílvio Lima, um místico da razão crítica, o. c., 12.

${ }^{31}$ João Paulo Avelãs Nunes, A História Económica e Social na Faculdade de Letras da Universidade de Coimbra. (.) 1911-1974, Lisboa, Instituto de Inovação Educacional, 1995, 27-28.

${ }^{32}$ A cifra de $20 \%$, aduzida por ANTÓNIO DE Oliveira, «As histórias da minha geração: uma perspectiva historiográfica», Estudos de Homenagem a Luís António de Oliveira Ramos, Porto, FLUP, 2004, II, 90, não aclara a natureza hegemónica que os ex-teólogos detêm no curso de Letras.

${ }^{33}$ A Faculdade de Letras da Universidade de Coimbra ao País, Coimbra, França Amado, 1919, 15-16.

${ }^{34}$ Em 1911 em Letras havia 21 matrículas; em trend de crescimento até meados de 1990 (com 4.000).

${ }^{35}$ Joaquim de Carvalho, Obra Completa, VIII, o. c., 84. 
Prevenções de ordem teosófica e teológico-dogmática recolhiam à casa no ensino da filosofia (e da história), impostas pela durável correlação de poder, pela repressão curricular e pragmática que assinalava a dupla vinculação censória e apologética do Estado e da filosofia de matriz teológica neotomista ${ }^{36}$ no retorno à situação da filosofia anterior ao espinosiano Tratactus, «contemporânea» pois das circulares que no Colégio das Artes impediam "novas opiniões" sobre o tomismo ou que sugeriam a Roma a inutilidade de livros novos que questionassem a doutrina antiga ${ }^{37}$. A filosofia muito dificilmente se desembaraçou da teologia para (se) poder pensar.

\section{Expurgos e outras (tentadas) tentações}

O expurgo simula e instiga a revolucionária novidade do arcano gesto. Indício da nova atitude expulsória, lentes e estudantes talassas são perseguidos. A referida Falange demagógica dos Olivais, arromba em 17 de outubro de 1910 as portas dos Gerais e destrói cátedras, gabinetes, insígnias, peças de arte e mobiliário nos Capelos, ameaçando lentes e funcionários com revólveres e tiros. Exige a suspensão de aulas até à total reforma universitária ou em alternativa até se iniciarem cursos livres. Leia-se o comunicado editado nos jornais dos «estudantes revolucionários de Coimbra»: “À hora em que sai este Manifesto, já os lentes foram expulsos das salas dos actos e já as cátedras desapareceram sobre os golpes violentos dos machados. (.) Este levantamento não tem em vista levantar embaraços à República nascente, mas simplesmente lembrar que a hora da justiça já despontou e que é necessário fazer justiça a todos". Decretados 6 dias depois, os cursos livres geram levas de licenciados com facilidades inauditas em provas, classificações, anos a salto. Enquanto, para se reabilitarem, docentes então demitidos assinavam o humilhante «atestado de Republicano» (ocorreu a José Tavares), nova modalidade em pública forma, no séc. XX, da profissão de fé dos conversos.

${ }^{36}$ Cf. P. ArChER, Sílvio Lima, o. c., IV parte, 400.

${ }^{37}$ Cf. J. S. Silva Dias, Portugal e a cultura europeia (.), Porto, Campo das Letras, ${ }^{2^{\mathrm{a}}} 2006^{\text {Biblos } 1952}$, 131-38. 
Implicados na dita conspiração de Coimbra de 1911, episódio menor das «incursões do Norte», alunos são riscados da Universidade. Extinto o foro improvisa-se um Tribunal Militar no antigo convento de Santa Teresa, em abril de 1913, sairiam absolvidos: Afonso de Vasconcelos, Agostinho Costa Alemão, Alfredo Sampaio, padre António Luís de Oliveira, Augusto César Bolotinha, Eusébio Soares, F. Alçada, Francisco Bourbon, Luís Antunes de Lemos, Soares Franco entre todos. Riscados, expatriados, Alberto Monsaraz e Luís de Almeida Braga tentam não perder o tempo que gastaram a "ouvir as prelecções dos juristas da Lusa Creta" e requerem o reingresso ${ }^{38}$; o antigo lente de Filosofia (Desenho) demitido, J. L. Mendes Pinheiro (à frente dos alunos do seu Colégio Liceu Figueirense), migra para monarquias católicas, Bélgica, Espanha. Alunos distintos, António Sardinha, Hipólito Raposo, descrentes da solução republicana vêem-se-lhes fechar as Faculdades quando aí tentam ingressar como assistentes. Raposo concorre em 1914 com Sentido do Humanismo, tese preterida em Filologia Românica, em Lisboa, dado o sentido «desfigurador» da língua e do sentimento nacional que o autor lê no Renascimento ${ }^{39}$. À época, escreve o insuspeito Sardinha ao secretário da Universidade de Coimbra: "Da Faculdade [de Letras de Coimbra] consta que nas esferas públicas não possui simpatias (.) Produz muito mal a acumulação enciclopédica dos padres e corre que eles fecham sistematicamente aquilo, enquanto não tiverem filhos próprios" 40 . Sardinha espera em vão que se abra concurso, mas não encontra esteios ideológicos e pessoais em Direito (Coimbra); e em 1915 acalenta idênticas expectativas na Faculdade de Letras de Lisboa, com $O$ Valor da Raça, tese vencida, não pelo larvar racismo cultural que positivismo e cientismo nutrem. Confessa em tom teofiliano: "isto é um país onde nem se reconhece o direito de mostrar o que a gente sabe" ${ }^{41}$. A antimodernidade

${ }^{38}$ M. a de Fátima Correia de Carvalho, «Correspondência de António Sardinha, Luís de Almeida Braga, Alberto Monsaraz, Alfredo Pimentas e Hipólito Raposo a Manuel da Silva Gaio», Arquivo Coimbrão, XXXI-XXXII, 1988-89.

${ }^{39}$ Cf. Hipólito Raposo, Sentido do Humanismo, Coimbra, França Amado, 1914, 71-76.

${ }^{40}$ Fátima Carvalho, «Correspondência de António Sardinha (.)», o. c., 84 e 107. Sub.ns.

${ }^{41} I d . i b ., 77$. Cf. P. ARCHER, «Três teses sobre a ucronia e a floresta utópica» RHI, 24. 2003, 389-90. 
não nasce em teses académicas mas em movimentos organizados, nos comícios, nas tribunas da imprensa reaccionária, como o Integralismo Lusitano, que reactualizam a inacabada ideologia do expurgo. O que a universidade expulsa pela porta entra-lhe pela janela.

Conservadores, católicos, reaccionários, têm visíveis dificuldades em integrar ex novo o corpo universitário. Em 1914, contesta-se na praça pública que o poeta e docente Eugénio de Castro $^{42}$, católico, aristocrata, monárquico, possa entrar no quadro para o qual fora convidado. O director do republicano Resistência, J. Martins Teixeira de Carvalho, objecta a qualidade científica e habilitações de Castro, nomeado por decreto (10 de Outubro de 1914) e transitado da Escola Industrial Brotero $^{43}$. Avaliada e dirimida a querela, o Senado Universitário, a 21 de novembro, conclui improcedentes as críticas, considerando o médico assistente Quim Martins parte interessada na regência de Arqueologia e Arte para a qual fora designado o poeta, dando a entender que este deteria invejável currículo (então no auge da aura europeia de demiurgo lírico) para que o oponente se pudesse pronunciar ${ }^{44}$. Em 1917, ou inícios de 1918, seria omitido na nomeação para a docência o então padre doutor Gonçalves Cerejeira ${ }^{45}$. Sabe-se por fonte idónea: "Meu pai e Cerejeira foram amigos e condiscípulos" - depõe oficiosamente um filho de Joaquim de Carvalho, o mestre coimbrão de história da cultura - "Fizeram em conjunto as suas provas de doutoramento. Ambos foram aprovados e com alta valoração. Chegada a hora das nomeações o ministro republicano só nomeou a meu pai. Deixou Cerejeira de lado. Meu pai vai a Lisboa e conversou com o ministro. Disse a esse republicano ultra: saiba V. ${ }^{\text {a }}$ Ex. ${ }^{a}$ se o meu colega Cerejeira não for também nomeado, e não o é por ser monárquico ou católico, eu não tomarei posse do meu lugar de assistente. O ministro não disse

${ }^{42}$ Cf. O Instituto, $109^{\circ}$, Coimbra, 1947, 97. Entrara em Letras instado por Mendes dos Remédios, do grupo «teológico»: “conheci Mendes dos Remédios há quasi meio século, em 1883, quando ele, um pouco mais velho do que eu, era um imberbe e franzino aluno do Seminário de Portalegre”, Biblos, VIII, 1932, 726.

${ }^{43}$ P. Archer, «Cartas de António Sardinha para Eugénio de Castro», Arquivo Coimbrão, XL, 2008, 7.

${ }^{44}$ A Universidade de Coimbra no século XX. Actas do Senado, I, (1911-1916), C. a , AUC, 1989, 134-37.

${ }^{45}$ Em março de 1918 já Cerejeira tem assento no conselho escolar como doutor. 
nada, meu pai voltou para Coimbra mas dias depois via com agrado a nomeação do dr. Cerejeira. Ambos tomaram as insígnias doutorais na mesma tarde, na Sala dos Capelos, mas Cerejeira fez questão de ser meu pai o primeiro a recebê-las..." ${ }^{46}$. Em 1919, a ser outro caso como se dirá, Cerejeira está no centro de um controverso ajuste de Letras.

A conjuntura - o fim da Grande guerra, presidencídio, trama militar e insurreições monárquicas em Monsanto e no Norte - instiga a arguição de germanofilia e monarcofilia a quatro docentes de Direito, Oliveira Salazar, Carneiro Pacheco, Magalhães Colaço, Fézas Vital (também Pacheco de Amorim, autor de A Nova Geração, e Mendes dos Remédios, reitor demitente solidário com os suspensos), por «ofensas à República». O ministério José Relvas cai por alegada tibieza antimonárquica; cabe ao ministro democrático Domingos Pereira (e depois ao seu ministério) robustecer a República, fragilizando a Universidade, no limiar da guerra civil que hesitações no perfil presidencial reflectem, recaído num monárquico ao serviço da ordem republicana, Canto e Castro $^{47}$. A querela iniciada a 14 de março ${ }^{48}$ aclara redes corporativas solidárias e indicia estratégias e retóricas da sobrevivência ideológica do grupo dos universitários integrado por Salazar. A fractura resulta do próprio confronto militar no qual estudantes republicanos participam, no Batalhão Académico, entre janeiro e fevereiro, contributo na região do Porto e Aveiro para derrotar a Monarquia do Norte de Couceiro. Na precária paz europeia, para sectores republicanos radicais em plena política de guerra urgia expulsar das cátedras os reaccionários, refere a historiografia dominante. Mas o frustrado saneamento político - após o término da Grande guerra e a derrota interna dos monárquicos - mais do que ilustrar a debilidade da instituição e do ministério, patenteia o modo como sectores hegemónicos da República afunilam na estratégia do regime e na sobrevivência política a pluralidade universitária.

${ }^{46}$ Bib. P. M. Figueira da Foz, Espólio Joaquim Montezuma de Carvalho, C PES 32. 2. Carta abonatória (1974) Dr. Silva Tavares. Dando-a por boa fonte, a similitude com o processo de 1919 suscita dúvidas (cf. infra).

${ }^{47} \mathrm{C} f$. Norberto Ferreira da Cunha, «A ordem e a Pátria na acção de um Presidente da República monárquico: Canto e Castro», Revista de História das Ideias, 27, 2006, 359-97.

${ }^{48}$ António Pedro Vicente, «Conflitos Académicos durante a $1^{a}$ República (.)», Actas 5, o. c., 337-400; J. FerreIRA Gomes, A Universidade de Coimbra durante a I República 1910-1926, Lisboa, I.I.E., 1990, 318-31. 
Ataques à convivência e tolerância democráticas, esteios da libertas res publicana, fragilizam a República.

Desenho novo na figura jurídica da expulsão: docentes visados são suspensos no decurso judicial do processo instrutório, com garantias formais e materiais de audição e contraditório - eles próprios editam folhetos autónomos de defesa, em geral apelando para a liberdade universitária, negando partidarizarem as aulas -, entregue ao qualificado magistrado António Maria Lisboa, depois presidente do Supremo Tribunal de Justiça, que no relatório sindicante declara não "proferir condenação por simples suspeições políticas". Do rol testemunhal, todos os professores deponentes de perfil republicano (Rocha Brito, Bissaia Barreto, Ângelo da Fonseca, Wittnich Carrisso, Alves dos Santos, Almeida Ribeiro, Filomeno da Câmara, Marques dos Santos, João Duarte de Oliveira, Arnaldo Norton de Matos), acham as acusações infundadas e solidarizam-se com os visados, na linha da Faculdade de Direito. São delatores dois estudantes (um é Alfredo Fernandes Martins) e um professor liceal (Sílvio Pélico, ex-colega de Salazar, concorrente então a prémios e acessits que obteve mas com menor brilho); Quim Martins, assistente nas Letras, acusa Fézas Vital e Colaço e defende Carneiro Pacheco. No cômputo, para o síndico é débil o teor probatório: sufrágios por D. Carlos, missas, vagas expressões críticas em aulas. As conclusões do inquérito, saídas em abril no diário oficial, improcedem delações e ilibam suspeitos. Indiciado pelo ex-colega seminarista José Rodrigues da Costa, agora seu aluno, Salazar repassa o passado - não fora orador sacro, bastava-lhe em Viseu ouvir oradores de maior nomeada como o teólogo Alves dos Santos; e Vieira da Rocha, lustre democrático agora mestre de Direito em Lisboa, seria um daqueles colegas "com mais dotes oratórios que eu". Marcara-o "muito a forma anti-religiosa - propriamente anticatólica - da realização democrática no mundo latino, contra aquela liberdade tão larga, tão magnânima, tão elevada, da Inglaterra, da Bélgica, dos Estados Unidos da América", tendo fé na "democracia como um facto histórico, uma corrente insuperável, uma conquista legítima perfeitamente conciliável com o catolicismo" ${ }^{49}$. Veja-se a praxiologia da doutrina, em 1935, na expulsão de Sílvio Lima.

${ }^{49}$ António de Oliveira Salazar, A minha resposta. (.), Coimbra, França Amado, 1919, 13; 18-19. 


\section{A falhada expulsão da Faculdade de Letras de Coimbra (1919)}

Carece análise modal o caso que suscita recente acervo de leituras desacertadas Em maio de 1919, a Faculdade de Letras é desanexada da Universidade de Coimbra e transferida para a do Porto pelo titular da Instrução no ministério Domingos Pereira ${ }^{50}$. Se não se desliga da sindicância de março-abril de 1919, não há seguro indício que estabeleça a clara natureza da polémica decisão, embora politicamente se alegue a putativa erudição livresca da orientação tomista calcando "as especulações originais do espírito moderno". O dissídio entre o ministro e a Faculdade coimbrã terá origem na deliberação de criar a congénere na Universidade portuense, na qual seria o líder? Ou a decisão de prover sem provas públicas professores ordinários, os assistentes Cerejeira e Joaquim de Carvalho, irá inquinar a decisão do ministro, que para esses mesmos lugares (decreto 5.491 de 2-V-1919), nomeara dois nomes da confiança pessoal e da Renascença Portuguesa ${ }^{51}$ ? E a 10 de maio, o decreto 5.781 abre em Lisboa a $1{ }^{\text {a }}$ Secção da Universidade Popular, reforçando a pressão sobre universidades oficiais.

Acareando, é razoável optar pela segunda hipótese: a proposta de nomeação de Carvalho e Cerejeira seria táctica antecipatória da Faculdade, face à imposição da nomenclatura ministerial, inviabi-

${ }^{50}$ Sílvio Lima, um místico da razão crítica, o. c., 20-30. Decreto n. ${ }^{\circ}$ 5.770, Diário do Governo, n. ${ }^{\circ}$ 98, I ${ }^{\text {Série }}, 1^{\circ}$ supl., 10-V-1919, 1229-30. Coimbra "meio essencialmente universitário, vivendo o professorado e corpo docente da Universidade como que insulado no seu trabalho especulativo, literário e científico", orientava "embora notavelmente, a cultura dos alunos de modo a darem preferência à erudição livresca sobre as especulações originais do espírito moderno", "manifestando-se na filosofia revelada nas obras dos seus principais professores uma quasi completa orientação tomista de forma escolástica" e dadas as "condições sociais da cidade do Porto", "de mais larga actividade que a de Coimbra", se transferia a Faculdade de Letras para a Universidade do Porto, criando em Coimbra a Faculdade Técnica com Belas-Artes, o que não sucederia.

${ }^{51}$ Diário do Governo, I ${ }^{\text {Série }}, 1919,729-30$, D-GES; e II ${ }^{\mathrm{a}}$, n. ${ }^{\circ}$ 102, 5-V-1919, propunha F. Newton de Macedo e Lúcio Pinheiro dos Santos, ligados à Renascença Portuguesa; $c f$. Ferreira Gomes, A Universidade de Coimbra durante a I República, o. c., 332. Difícil de dirimir pois as datas dos decretos não coincidem com as da publicação em Diário do Governo, tendo sido posteriormente fixadas como refere parte interessada no processo - DAmiño Peres (História de Portugal, Suplemento, Porto, Portucalense, 1958, 250). 
lizando, pois era público ${ }^{52}$, o intento que o ministro Leonardo Coimbra propalara (na manhã da tomada de posse), de "acabar com a Universidade de Coimbra" ${ }^{53}$, discricionária medida pombalina no modo como fundamenta a extinção da Escola ${ }^{54}$. O conselho de Letras protesta, na sessão ordinária de 14 de maio, contra o "sobressalto" do "imprevisto documento" (dec. 5.491), dado o "profundo desconhecimento do mérito dos nomeados" e respectivos curricula, para integrarem a instituição, ignorando-se aptidões pedagógicas e científicas; nomeação que atropelava os mais elementares deveres de prévia auscultação da secção de histórico-filosóficas e que contrariava o

52 "Devia desaparecer, porque, existindo agora as Universidade de Lisboa e do Porto, não há necessidade de manter uma terceira Universidade cuja existência é apenas um respeito às tradições" - entrevista de Leonardo Coimbra ao jornal A Manhã , n. ${ }^{\circ}$ 774, 21-V-1919.

${ }^{53}$ É a interpretação, pensamos correcta, de José de Mendonça Fava in Leonardo Coimbra e a Primeira República. Percurso Social e Político de um Filósofo, Coimbra, IU, 2008, 82, 173-74; José Gomes Ferreira, A imitação dos dias. Diário inventado, Lisboa, Portugália, 1970, 158. Mário SANTIAGo de CARVAlHo, «Filosofia e Universidade. Em torno de um episódio da História da Filosofia na Faculdade de Letras deCoimbra»,Revista Filosófica de Coimbra,n. . 33, 2008,18-36, na autoridade de Miranda Barbosa e Gama Caeiro deduz que o ensino filosófico se teria norteado pelo estrito carácter formativo generalista, historicizante, positivista (ib., 34), de 1911 até à reforma de 1957, ápice, na perspectiva do prezado autor, genético do movimento de modernidade e exigência intelectual com o reforço logicista da filosofia perene e da excelência da «ontologia» lusíada como o afirmam as suas fontes ( $c f$. F: G. CAEIRO, «Miranda Barbosa e a Filosofia em Portugal», in AAVV, Introdução ao pensamento filosófico de A. Miranda Barbosa, Lisboa, IN-CM, 1997, 105-18), lúmen ao qual se opõe, no relógio solar da democracia, a penumbra da "hora difícil (acaso sombria) da universidade portuguesa" (CAEIRO, cit, 118). Diga-se que o articulado dos decretos de Leonardo é eivado de «indelével» positivismo (introduzir Química, Física e Biologia no quadro curricular da Filosofia, explicito telos cientista) e vanguardismo jacobino. A hipótese de ser Alves dos Santos um dos visados é espúria, como se provará; e a avocação testemunhal de Caeiro et alii inutiliza a apreensão do esforço resistente de Joaquim de Carvalho no seio da obediência corporativa ao his master's voice. Não se entende, assim, como historiar o mundo filosófico de Joaquim de Carvalho (ib., 35) sem ir pela própria obra. Não é tanto um episódio da «História da Filosofia», senão dum episódico histórico, de matriz política (projecto de poder), que pretexta a filosofia para politicamente se afirmar.

${ }^{54}$ Embora com imprecisões, cf. o que aduz Miguel ReAL, «Joaquim de Carvalho (1892-1958) - um liberal heterodoxo», Litorais, Revista de Estudos Figueirenses, ano 5, n. $^{\circ} 9,2008,43-44$. 
anterior parecer do conselho. Por não subsistir argumento de natureza científica, dificilmente se aceitaria em Coimbra a "exclusão de matérias mais intimamente relacionadas com as especulações filosóficas", razão pela qual se reiterava a decisão antes tomada de "requerer a imediata suspensão do mencionado decreto". Logo a Faculdade edita dois opúsculos ${ }^{55}$ com detalhe e informação segura expondo a actividade pedagógica e científica em cerrada defesa dos docentes, em particular Cerejeira e J. de Carvalho ${ }^{56}$.

Leonardo publica dois anos depois a peça que esgrimiu no Parlamento com o lente evolucionista, Alves dos Santos, em abono da extinção da escola de Coimbra. Em A Questão universitária, que reproduz o seu último discurso parlamentar sobre o assunto, já na qualidade de deputado por ter caído entretanto o governo, em nome da "aceleração social" e do prodigioso avanço das Ciências que todos os dias "dão à técnica social valores novos", defendia que as universidades deveriam ser "grandes factores da evolução da crença" "57, "força de coesão entre associações de certos estados psíquicos". E insistia: "é assim que sempre que um bando tenta impor uma crença adormeça o espírito num dado associacionismo psíquico, esse bando vai à conquista das Universidades"; tomando a exemplaridade histórica dos Jesuítas em Portugal, o bando "começa sempre por pedir a liberdade de ensino para se introduzir, e depois irá, sempre que possa, até exigir o monopólio do ensino nas suas mãos". Ora, fora "a esta luz que sempre olhei as Universidades e, quando da minha nomeação para ministro, numa entrevista ao Mundo eu disse que

${ }^{55}$ Universidade de Coimbra // Faculdade de Letras // Texto de um Decreto eminente anunciado pelos jornais (1) / Texto da representação a que se refere o Decreto anterior (2), Coimbra, França Amado [1919], texto datado pelo secretário do conselho, Eugénio de Castro, a 15 de Maio de 1919; 2.

${ }^{56}$ Em rigor, em questão está o perfil eclesiástico e conservador de Cerejeira. Cf. A Faculdade de Letras da Universidade de Coimbra ao País, C. ${ }^{\text {, }}$, França Amado, 1919, 22-23: na sala do reitorado "o moço Joaquim de Carvalho infligiu ao Reitor sr. Coelho de Carvalho uma tremenda lição de nobre e altiva independência - declarando-lhe que não aceitava a nomeação que o separasse do seu colega [Cerejeira], como ele, Reitor, pretendia". Concertando exclusões, Cerejeira e Carvalho em Coimbra e Leonardo, no Porto, seriam nomeados no mesmo decreto ministerial, de 5 de Novembro de 1919, como professores efectivos (cf. GEPeB, VI, 78).

${ }^{57}$ Leonardo Coimbra, A Questão universitária, Lisboa, Portugal-Brasil, Soc. Ed., s. d. [1921], 6 e 9. 
as Universidades, embora cheias de valores isolados, não correspondiam à sua alta missão social", pois lhe faltaria (a Coimbra), "nobre espírito de Liberdade", provando "a sua impotência de afirmar, perante a grande guerra, a sua ausência de renovamento social" à revelia de Guyau, para quem a Escola deveria aceitar a "equivalência entre a interioridade ou profundeza da vida e a sua exterioridade ou vastidão". Concluía: "não quero dizer que a Universidade é jesuítica; demonstrei que ela dormita sobre os bens espirituais da Pátria" 58 .

Inegável suspeição teológica devolve à FLUC: senão jesuítica, é tomista, provando perseguir o projecto pessoal de fundar no Porto a Faculdade de Letras, o que ocorre a 27 de agosto, que dirige e na qual coopta os que gravitam na Renascença Portuguesa, a "Faculdade das Tretas" e "Capelinha do Leonardo", como émulos políticos e vox populi verrinaram, dada a exiguidade material, sobretudo a original metodologia de provimento. O ministro criara o próprio bando, bem entendido: Newton de Macedo, Hernâni Cidade, Damião Peres, Teixeira Rego, doutores sem Actos por certidão político-administrativa ${ }^{59}$, dos quais logicamente Leonardo é o primeiro laureado ${ }^{60}$. Escola efémera, extinta em nome da salvação financeira (1928, com a Escola Normal Superior e as Faculdades de Farmácia em Coimbra e de Direito em

\footnotetext{
${ }^{58}$ Id.ib., 9-12 e $18 ; 21 ; 29$.

${ }^{59}$ Francisco Miguel Araúuo, Faculdade(s) de Letras do Porto: da (re) criação à revolução, Porto, FLUP, pol, 2008, 57. "Escola desde logo caluniada, pelos que a diziam pura criação política" afirma o ex-secretário de L. Coimbra, depois director da Faculdade coimbrã, Damião Peres (o. c., 251), "desamparada dos próprios poderes que a tinham criado, pois, nos primeiros anos, teve de viver, quase exclusivamente, tanto da abnegada acção dos seus professores, que ocorriam com milagres de devoção pedagógica à insignificância do material e à miséria das instalações, como da compreensiva dedicação e do anseio de saber dos seus estudantes".

60 "O principal argumento que denegriu a imagem da instituição era precisamente a sua maior especificidade na estrutura universitária portuguesa, o polémico modo de provimento dos docentes com dispensa dos regulares concursos de admissão, amplamente reprovado em todos os meios académicos", modelo em uso nas universidades mas "nenhuma possuía um corpo docente nomeado exclusivamente por determinação ministerial como a mais recente das faculdades". Em 1921, os iniciais dez docentes entrariam nas cátedras sem provas públicas; administrativamente doutorados, gerando um coro de protestos pelo país (ARAúJo, o. c., 87-90).
} 
Lisboa, esta $\log$ o reaberta ${ }^{61}$ ) e encerrada em 1931. Duplo signo do crescente peso de Salazar no governo e de reparação à velha corporação, recriando nova expulsão universitária.

O dissídio evidencia a estrutural debilidade jurídica em que assentam não só o ensino das Letras em Coimbra, mas as universidades. Típico conflito de faculdades e aptidões de que fala Kant, estruturado a partir do conflito mais alargado de natureza político-ideológica, o governo, que não ensina, quer passar a ensinar através de interpostos agentes passando por cima dos eruditos corporativos. Mais notório por precisamente ocorrer na Faculdade menor, na tipologia de Kant, a de Filosofia, que se deveria orientar não pela sanção das doutrinas oficiais da governação mas pela razão do «povo erudito» e racionalmente determinada pela livre procura da figura da verdade ${ }^{62}$, em nome da qual seria utensílio de aferição das Faculdades «maiores» das quais seria a maior, afinal, pois actua como dispositivo de vigilância racional sobre os saberes úteis e práticos que estas ministram ${ }^{63}$.

É porém acessível outro auto documental que permite avaliar a extensão do problema e extrair ilações. O teor das Actas do Conselho Escolar de Letras, ilumina os contornos da questão, sem lhes responder cabalmente. No ano anterior tensões intra corpus afloram no debate da reestruturação curricular. Em intenso período de reuniões, desde 9 de março de 1918 (pela primeira vez têm assento no conselho, como assistentes, os novos doutores Simões Neves, Cerejeira e Joaquim de Carvalho), é discutido o projecto de reforma curricular, registando-se numa sessão "prolongada discussão" imperceptível, pois não se

${ }^{61}$ Universidade de Lisboa, Faculdade de Direito. Razões justificativas da sua manutenção, Lisboa, Tip. An. Comercial, 1928, 5-15. O senado avoca a tradição histórica, projectos refundadores Mouzinho de Albuquerque e Figueiredo e Almeida (1835-36), realizados em 1913; "não pode negar-se a esta Faculdade o direito de viver, nem em nome de economias a realizar no Orçamento", menos "em nome de quaisquer princípios pedagógicos", conquanto "nenhum sistema é mais condenável que o do monopólio de um ramo de ensino por uma escola privilegiada". Rejeitando o modelo de Letras portuense, subscrevem o manifesto "professores feitos - que invocam com orgulho o facto de terem conquistado, todos, as suas cátedras por concurso de provas públicas".

${ }^{62}$ Dado o eclipse da Teologia. $C f$. I. Kant, $O$ conflito das Faculdades, Lisboa, Edições 70, 1993, I, 18-22.

${ }^{63}$ Id. ib., I, secção, II, 30-33. 
trasladam conteúdos à boa maneira da burocracia pátria ${ }^{64}$. O director Vasconcelos, católico síntono na conjuntura sidonista, congratula o novo Estatuto Universitário e a lei orgânica da Faculdade de Letras ${ }^{65}$ que autonomiza para efeitos de doutoramento a $4^{\text {a }}$ Secção de História em História e Geografia ${ }^{66}$. Faculdade e universidade coniventes ${ }^{67}$ enlaçam-se ao ex- vice-reitor. A casuística conservadora ilumina os trabalhos do conselho escolar e a pugna que motiva a temporária extinção da Faculdade, em 1919. Ora, com base no art. 55 do Estatuto e nas moções de Vasconcelos e Alves dos Santos, a 7 de maio por unanimidade propõe ao governo a nomeação de professores ordinários, com dispensa de provas públicas, dos assistentes G. Cerejeira, no $4^{\circ}$ grupo (históricas) e Joaquim de Carvalho no $6^{\circ}$ (filosóficas), atendendo a "importantes trabalhos de investigação original, por estes Doutores realizados, e de que têm dado sobejas provas"68. A 12 de maio, em sessão extraordinária o conselho inteira-se (através do telegrama do secretário

${ }^{64}$ Acta de 21 de março de 1918 in A Universidade de Coimbra no século XX. Actas da Faculdade de Letras, vol. I (1911-1925), Coimbra, Pub. AUC, 1989, 145.

${ }^{65}$ Acta de 31 de julho de 1918, ib., 149.

${ }^{66} \mathrm{Cf}$. Acta de 18 de novembro de 1918, ib., 151.

${ }^{67}$ A 17 de janeiro de 1918, Sidónio visita a Universidade, assina o apreciado aumento de ordenados (Acta de 6-II-1918, ib., 142), reempossa o reitor e homem forte da República Nova, Mendes dos Remédios (1867-1932) e trocam-se congratulações (18-XI, ib., 150) pelo Armistício. Para o admirador do ordeirismo germânico, a vitória Aliada seria sinal da mística colonial e nacionalista-M. NuNES Ramalho, Sidóno Pais. Diplomata e conspirador (1912-1917), Lisboa, Cosmos, 2001, XXII-XXV; 28-29; Alice Samara, Verdes e Vermelhos. Portugal e a Guerra no ano de Sidónio Pais, Lisboa, Notícias, 2003. Após o presidencídio, o conselho de Letras presidido pelo reitor protesta "contra o vil atentado do dia 14" e "comemora em sentidas palavras", de Remédios, "altos benefícios prestados à Universidade de Coimbra em especial à Faculdade de Letras pelo glorioso e malogrado Presidente". Assinam a acta,caso excepcional,todosos docentes e assistentes provisórios-Actade 23-XII-1918, ib., 153-54. Para "perpetuar a memória" o conselho adopta medidas que, não passsando do papel, relevam da protecção de Sidónio à casa-mãe ( $c f$. ib., 152-53); o Museu Sidónio Pais (rebaptismo do projectado Museu de Arte Antiga e Medieval previsto para o "majestoso salão central da Faculdade de Letras"), e um "quadro de mármore" com os nomes dos beneméritos da Faculdade, primeiro "em letras douradas, o nome do Dr. Sidónio Pais"; além da atribuição anual de dois "Prémios Sidónio Pais" para distinguir os dois melhores alunos da Faculdade e de "Bolsas de Estudo Sidónio Pais", das quais também não mais se falará.

${ }^{68}$ Acta de 7 de maio de 1919, ib., 155-56. Esta proposta foi tornada pública no opúsculo A Faculdade de Letras da Universidade de Coimbra ao País, o. c., 21-22. 
do ministro, Duarte Ferreira) que "todos os alunos dessa Faculdade" se insurgem contra o carácter eliminatório dos exames escritos, dado o anómalo ano lectivo e exigem perdão de actos, e argúi a autenticidade do despacho, "pois lhe parece estranho" a Oliveira Guimarães, "que S. ${ }^{a}$ Ex. ${ }^{a}$ o Ministro que, para assuntos mais graves do que este, não tem procurado conhecer a opinião da Faculdade, se lembrasse agora de a ouvir sobre um assunto que apenas importa uma interpretação da lei orgânica" ${ }^{69}$.

Remédios, o mentor da Biblos (1925), reitor auto-suspenso contra a aludida sindicância aos juristas, é ab-rogado pelo bacharel da confiança política do ministro, Coelho de Carvalho ${ }^{70}$, ex-presidente da Academia de Ciências estranho à fechada hierarquia corporativa, persona non grata nas Letras, refere Joaquim de Carvalho ${ }^{71}$, "gosta que o venerem como prelado universitário", "passeando-se de guarda à porta-férrea, arquiepiscopalmente". Dado o incumprimento de prazos e exames num ano lectivo conturbado, Remédios, com Ferraz de Carvalho, quer indagar da razão das reclamações estudantis. Mas Alves dos Santos é peremptório no indeferimento sumário da petição dos alunos, assentindo apenas na dilação da época de exames ${ }^{72}$. Fissura que não se consegue fechar.

Nova sessão extraordinária do conselho, a 14 de maio, reclama do teor do decreto n. ${ }^{\circ} 5.491(2-\mathrm{V})$, pela "inesperada nomeação" sem prévia consulta, de dois docentes para a secção de ciências filosóficas (para a qual fora proposto Joaquim de Carvalho) com o intuito de colmatar, nos termos do decreto, "matérias indispensáveis ao aperfeiçoamento e expansão da alta cultura intelectual no domínio das ciências filosóficas", tomando-a como "profundo agravo feito à Faculdade" pelo que esta requer "a imediata suspensão do mencionado decreto" e redige a representação de protesto já referida ${ }^{73}$, momento decisivo do corte

${ }^{69}$ Acta de 12 de maio de 1919, Actas da Faculdade de Letras, o. c., 157.

${ }^{70}$ (1852-1934), advogado, seguiu a carreira consular da qual é afastado e regressa ao país, com dispersa obra sobre pedagogia (a adaptação do método João de Deus), traduções, teatro e páginas memoriais. Cf. infra nota 85.

${ }^{71}$ Johquim de Carvalho, A minha resposta // (.), Coimbra, Tipografia França Amado, 1919, 14.

${ }^{72}$ Acta de 12 de maio de 1919, o. c., 157.

${ }^{73}$ Acta de 14 de maio de 1919, ibid.,158-59. 
de relações com Leonardo Coimbra ${ }^{74}$, professor do ensino secundário preterido em concurso de Lisboa (contra Sérgio e Matos Romão) que aspirava à cátedra.

Sobre Alves dos Santos recaí a suspeita de ter colaborado ou elaborado o decreto saneador, de inegável leitura positivista. No Parlamento acusará o incapacitante confessionalismo dos ex-teólogos seus colegas ${ }^{75}$; reforçando a estratégia sectária do ministro em carta endereçada - da Câmara de Coimbra - à sessão do conselho de 21 de maio, demite-se de todos os cargos (director do Laboratório de Psicologia Experimental, delegado ao Senado, regente de História Moderna e Contemporânea), decidindo "não assistir mais a quaisquer reuniões de professores que não sejam determinadas por motivo de serviço de actos ou exames" 76 . Ao concordar com a reorganização proposta pelo decreto n. ${ }^{\circ} 5.491$, reafirma "que nenhumas responsabilidades tem nessa reorganização" e declara "acatar o acto do poder executivo", achando "inconvenientes e inoportunas quaisquer observações ou reparos que porventura se intentem fazer" à reestruturação e nomeações ${ }^{77}$. Isolado, propõe em carta particular ao ministro que o transfira para Lisboa, desvinculando-se do protesto dos "reaccionários". Divulgada a carta na imprensa, o conselho, dada a "inqualificável atitude assumida pelo professor Alves dos Santos", como "cruel mas justo castigo de quem o merece", transcreve-a em acta ${ }^{78}$ :

${ }^{74}$ Improcede a leitura do teor antipositivista (A. Quadros, O. Vitorino, - cf. M. S. CARvalho, o. c., 19-20) do decreto de Leonardo; Alves dos Santos não era o alvo a abater (id. ib., 29), mas, como se vê, ele próprio se solidariza com o ministro e lhe propõe a extinção da Faculdade, se este o colocar em Lisboa. A cisão é póstuma.

${ }^{75}$ L. Coimbra no parlamento ( $O$ Mundo, n. ${ }^{\circ}$ 6.532, de 25-VI-1919): "É que há professores da velha faculdade de Teologia, e que fazem parte da Faculdade de Letras, que, pela sua formação psíquica, como disse o Sr. Alves dos Santos encontrando-se dentro de confissões religiosas, não podem oferecer, para um dado ensino, as garantias de neutralidade e imparcialidade que esse ensino requer"; cf. M. Santiago de Carvalho, o. c., 19.

${ }^{76}$ Acta de 21 de maio, Actas da Faculdade de Letras, vol. I, (1911-1925), o. c., 160 .

${ }^{77} \mathrm{Ib} ., 161-62$.

${ }^{78}$ Acta de 30 de agosto, ib., 166. Proverbial a elasticidade de A. dos Santos: em 1909, na oração fúnebre na capela da Universidade jurara "glorificar a vida do Rei e do Príncipe" (O Regicídio, Coimbra, sep. dos Anais da Universidade, 1909); meses depois (1910), é chefe do gabinete de Teófilo Braga no governo provisório. 
"Meu Ex. ${ }^{\text {mo }}$ Amigo: A minha Faculdade está em rebelião contra o Governo. Não a acompanharei, porque, no fundo, o movimento é reaccionário e é dirigido por reaccionários. Isto é um protesto para desforras e represálias de despeitados e de cabotinos. // Coelho de Carvalho deve tê-lo posto ao facto de tudo. Leia essas cópias de dois documentos que eu enviei aos meus ilustres colegas. É a minha atitude. Mas terei de ficar entre eles? Em Lisboa não há laboratório de Psicologia Experimental. Parece que por lá nunca se pensou nisso. Porque não me encarrega de organizar esse laboratório? Os daí não gostariam? Transfira-me então para a Faculdade de Letras e para a Escola Normal Superior de Lisboa, por forma que fique em situação análoga à que aqui tenho."

Não transferido, o deputado Alves dos Santos irá pedir contas no Parlamento a Leonardo Coimbra, em junho de 1919. Entretanto, só a 21 de maio o conselho de Letras se pronuncia contra a extinção, alegando saber apenas "pelos jornais" pedindo sessão urgente do Senado ${ }^{79}$; este opor-se-á ao violento atentado à "integridade universitária" num opúsculo documental. O movimento estudantil defende a moribunda Faculdade - Marques da Veiga, Aarão de Lacerda, Albuquerque Rodrigues, J. Viana, Duarte Silva (delegado estudantil de Lisboa), Cancela de Abreu, Rui Gomes e Serras Pereira ${ }^{80}$, de quem se irá falar. A assembleia magna (24 de maio) vota a greve, Lisboa e Porto solidarizam-se no final do mês; os docentes de Coimbra fazem representação ao Parlamento a 25 , após moção do Senado. Na opinião pública a vaga de protestos condiciona a curto prazo a queda do ministério e um acordo parlamentar estabelece Faculdades de Letras em Coimbra e Porto ${ }^{81}$. O modo como E. de Castro redige a acta facultativa desvenda cálculo do conselho, votando enviar um telegrama ao presidente da República e ao primeiro-ministro exprimindo "surpresa e profunda

${ }^{79}$ A norma de extinção só foi publicada em Diário do Governo em suplemento de 22 de maio.

${ }^{80}$ Damião Peres, História de Portugal, o. c., 250.

${ }^{81}$ F. Araújo, Faculdade(s) de Letras do Porto, o. c., 53-54. Rómulo DE Carvalho, o. c., 690-91. Graduados de Lisboa e a sua Associação Académica, aprovam unânimes a moção solidária com os colegas de Coimbra, na "atitude nobre de protesto e defesa do prestígio universitário" com a "mais alta simpatia e dedicado apoio" (Acta de 23 de maio, o. c., 162-63). Teófilo Braga, em nome da Academia das Ciências de Lisboa, que integra desde 1889 (inactiva a republicana Academia das Ciências de Portugal, 1908-1913), apoia a pretensão coimbrã. 
mágoa por haver assim capitulado o facto de a Faculdade ter exercido, em termos dignos e correctos, como é próprio da honorabilidade de todos os seus membros, o direito de representação" ${ }^{82}$, anteriormente firmado em documento enviado ao ministro, a quem, novamente na reunião de 23 de maio, o conselho "pela última vez reunido" acusa ter afrontado o "mundo culto", pois "julgando e condenando o ensino desta Faculdade, sem dele haver previamente inquirido", "exprobrando na sua orientação aquilo que constitui o seu mais natural predicado, extinguindo-se, e mutilando assim a gloriosa e florescente Universidade de Coimbra", esmagava primários direitos de defesa constitucionalmente consagrados "às corporações, como aos cidadãos" o coimbrão Dias Pereira alterca com o ministro; já a 11 de junho, um grupo de lentes republicanos liderados por Ângelo da Fonseca impugna a decisão daquele ${ }^{84}$, depois aduzindo provas da inaptidão cívica do reitor ${ }^{85}$. Não só ius gens e ius corpus, estatutária autonomia, perigam: a corporação sufocada pelo ministro não se revê de modo radical no reitor ${ }^{86}$. Republicanos, Teófilo Braga, Brito Camacho, José de Magalhães, Fernandes de Mira, Santiago Prezado, adensam a posição universitária coimbrã. De alegadamente «filosófico» passou a político conflito «legal» pela autonomia do poder espiritual. Contestado,

${ }^{82}$ Acta de 21 de maio, o. c.., 161.

${ }^{83}$ Acta de 23 de maio, o. c., 163.

${ }^{84}$ Damião Peres, História de Portugal, o. c., 250-51.

${ }^{85} \mathrm{Cf}$. AUC, Polícia Académica, IV, $1^{\mathrm{a}}$ Esq., 10. 5. 22. Cf. tb. proc. Ângelo da Fonseca. Na reunião de 27 de maio no Inst. de Antropologia, Ângelo da Fonseca encarrega-se de avocar a causa universitária. Através duma firma lisboeta de advogados, requer em 14-VI-1919 ao Supremo Tribunal Administrativo a extracção do processo de exoneração do cônsul de Portugal em Xangai, Joaquim José Coelho de Carvalho, demitido por portaria de 25-XI-1886 (Diário do Governo, n. . 272, 29-XI-1886). Consta da certidão apensa: "Contraiu dívidas particulares, que deram motivos, pela sua insolvência, a apreciações desfavoráveis da imprensa para a sua representação oficial, a conflitos indecorosos e às perseguições dos seus credores, que se tornaram públicas e notórias, resultando d'uma delas a sua prisão em Hong-Kong, da qual se libertou por fiança dada pelo Governador de Macau, importância de 2.488 patacas que o Governo português pagou" e outros desfalques (227 libras, dois shelling e 9 pence, a 3-XII-1886 a que se segue a 28-XII avultada lista). Coelho de Carvalho vendera "impostos particulares" a portugueses em Macau, faltara a encontro com o cônsul italiano, falha técnica grave entre outras que estorvaram as relações diplomáticas entre a China e o governo de Macau.

${ }^{86} \mathrm{Cf}$. Acta de 23 de maio, o. c., 161; 164. 
o ministro a 3 de junho encerra as aulas, face ao protesto estudantil e à intervenção armada da formiga branca ${ }^{87}$, política armada para silenciar revoltosos. Mas o ministério cai vinte dias depois e o reitor vinte e três.

No tufão, replica Joaquim de Carvalho à dita ausência de "especulações originais do espírito moderno" e prevalência da "quási completa orientação tomista de forma escolástica" da instituição, contra-acusando Leonardo Coimbra de miserável sectarismo. Chumbada de rara pontaria, tais alvos atinge. Num folheto formalmente similar às respostas dos juristas visados na sindicância, Carvalho não fala em nome da Faculdade, esta o fez, ou da secção de Filosofia; na $1^{a}$ pessoa abre a capa à corporação mas distancia-se do registo filosófico e pedagógico conservador desta e da prepotência ministerial quer, no plano ético, da atitude de (Alves dos Santos e) Leonardo: “Acompanhei desde o seu início a Renascença Portuguesa e, quando ela fundou em Coimbra uma Universidade popular dei-lhe o melhor da minha sinceridade. Esta generosa tentativa faliu, infelizmente. À sua inauguração veio assistir o sr. Leonardo Coimbra. É ao espírito que então nos animava, e ao qual fiquei fiel, que o reputo traidor, com a sua obra miseravelmente sectária de hoje". Libelo cautelar da livre pesquisa filosófica, herança neokantiana de Marburgo na hegeliana realização histórica do Espírito, visava "converter os meus alunos de escolares em estudantes, sugerindo-lhes que estudar não é só aprender coisas, e frequentar uma biblioteca na época heróica, que é a vida académica, deve equivaler a dialogar com Platão, ouvir Kant ou passear com Goethe no parque de Weimar..."88.

Por não se imolar na ara nieztscheniana da "mosca da praça pública" que voara do Zaratustra, ironiza na resposta ao poder político ("pensam assim os tomistas de forma escolástica"), contestando no arbítrio censório ministerial a falha da tolerante cultura democrática no governo da República: "Se querem que façamos cursos de política partidária, tenham a coragem de o dizer", pois "se há uma estrutura mental que a República deve destruir é o da purificação. Para purificar o espírito, queimavam-se corpos; impediam-se leituras; fiscalizava-se o pensamento", traduzindo na ordem social a estagnação e na ordem

\footnotetext{
${ }^{87} C f$. Pedro José da Cunha, O Conflito universitário, Lisboa, 1921; Rómulo de Carvalho, o. c., 690-91.

${ }^{88}$ Joaquim de Carvalho, A minha resposta (.), o. c., 6 e 9.
} 
individual "o ódio tão arreigado na nossa constituição psicológica" $\mathrm{O}$ tiro certeiro do figueirense é testemunhado. Vem à Faculdade o reitor interino, Fernandes Costa, "para dar maior solenidade a esta sessão em que os novos professores Drs. Joaquim de Carvalho e Gonçalves Cerejeira pela primeira vez ocupam os seus lugares no Conselho, e repita a esses novos professores as saudações que já teve o prazer de lhes dirigir no acto de posse". Sessão de saudações e agradecimentos ${ }^{90}$. $\mathrm{Na}$ fotografia de família à volta da sobrevivência instante a corporação reúne (notícia alguma sobre Alves dos Santos). Se há indícios de colisão com outros corpos, latente com Direito ${ }^{91}$, o assalto ao reduto coimbrão porfia: em 1924 alveja-se o ensino comercial e industrial.

\section{Expurgos médicos, terapêuticos e psicológicos: à volta da alma}

A greve estudantil de abril de 1921 culmina o confronto que visa indeferir o exercício da cátedra sob pena de autoexclusão. $\mathrm{O} V$ ano médico e parte da academia rejeitam um lente e depois o reitor Oliveira Guimarães, inábil gestor do consenso mínimo para debelar a crise cuja pública repercussão o impele à demissão, desencadeada contra o panegírico que Ângelo da Fonseca terá feito em 27 de fevereiro de 1921 no túmulo de Daniel de Matos, prestigiado médico republicano (com José Falcão funda o jornal A Justiça, em 1878), antigo reitor que impedira com Elísio de Moura a extinção da sua faculdade em Coimbra em 1911. Provando-o, os alunos delatam o plágio do elogio fúnebre de Bernardino Machado, vinte anos antes, a Augusto Rocha, colega de Daniel de Matos. Num caso de inegável uso político,

${ }^{89}$ Cf. id.ib., 15-16.

${ }^{90}$ Acta da sessão extraordinária 25 novembro de 1919, o. c., 169.

${ }^{91}$ Mal-estar patente no Estado Novo, ata-se à precedência intelectual e escolar a que Direito se arroga e o grande crescimento das Letras, que a supera na frequência. Joaquim de Carvalho (também jurista) a Eugénio de Castro, afirma em carta de 17-VIII-1935, "que não tinha tempo para responder a certos importantes figurões da Fac. de Direito, que consideram a nossa Fac. o «cano de esgoto» da deles, escolhendo um assunto que participam das duas faculdades. Isto entristece-me". - BGUC, Resvs. Epistolário de Eugénio de Castro, Cx. 5. 
de ataque à visão republicana da Medicina (anota Bissaia ${ }^{92}$ ) na pessoa do seu primeiro legislador-reformador, fica por responder se não será reparação nortenha da derrota política imposta a Leonardo Coimbra em $1919^{93}$. É viva a memória da tomada da Bastilha (1920), sagrado «feriado académico»: na aula de 1 de março de 1921 alunos exigem ao lente a substituição; em 18 de abril a assembleia magna arromba portas dos Capelos e solidária vota a greve geral até à sua permuta, para que os quintanistas "não tenham de retirar-se da Universidade que sempre têm defendido" 94 , lê-se na moção aprovada. Desde 6 de maio o jornal $O$ Conflito, o porta-voz académico, acusa Fonseca, com inusitada violência visual e verbal, de "monstro moral" e do Porto, no Jornal de Notícias, o director do Instituto Médico de Portugal, António Coelho (tio do quintanista premiado Eduardo Coelho, dirigente do protesto e autor do texto do «verdadeiro» tributo a Daniel de Matos) desfere ataque cerrado a Oliveira Guimarães, o "renegado padre" que traíra grego e troianos, isto é, Fonseca e alunos, acusando-o de "loucura moral" e "imbecilidade" 95 . Apedrejados consultório e casa de Ângelo da Fonseca, a 18 de Maio, Guimarães, reitor interino, demite-se e é substituído por Fernandes Costa. Autodecretada a suspensão da praxe, trajes e festas académicas, em outubro a jorna recrudesce com a morte do estudante Ernesto Pires Camelo em sequência dos graves confrontos com polícia e populares. Reequaciona-se a autoexclusão quando um acordo suspende as hostilidades.

${ }^{92}$ Bissaya-Barreto (Subsídios para a história, VI (.), Coimbra, Imprensa de Coimbra, 1961), acusa Elísio de Moura de ser o "autor e animador" da greve, ao denunciar o plágio aos quintanistas (ib. 294; 297-99).

${ }^{93}$ Os lentes médicos vêm em Fonseca "devotado Amigo da Universidade, mais uma vez tendo posto o seu valimento pessoal e politico ao serviço da integridade deste estabelecimento de ensino e dos direitos de muitos dos seus professores" - António Coelho, A questão de Coimbra. Liquidação de um miserável Reitor (.) (o renegado padre Oliveira Guimarães), Porto, Tipografia Porto Médico L da 1921 , 75 , cl. 2, sub. ns.

${ }^{94}$ Permanece o modelo de autoexclusão. Na greve de 28 de maio de 1924 , o protesto académico contra a brutal repressão policial (originada na clivagem social e territorial futricas / estudantes) concita o necessário apoio do Senado em vista à satisfação da petição estudantil na posterior exoneração do comissário da polícia.

${ }^{95}$ A. Coelho, o. c., 62, cl. 2. 
Embora dirigentes estudantis neguem qualquer nexo político-partidário, no Parlamento não só democráticos acusam a greve reaccionária . Coelho, advogando em causa própria, "republicano por temperamento e por educação científica e filosófica", "da austera escola de Rodrigues de Freitas, José Falcão, Sampaio Bruno e Azevedo de Albuquerque", afirma não ter solicitado "à República o menor favor, o menor proveito, a menor honraria", declarando-se sem filiação partidária, sentindo-se "melhor dentro da Republica do que dentro de qualquer facção". Pelo contrário, em sua opinião, o reitor apenas contava com o miserável currículo de "ex-padre, ex-monárquico e ex-sidonista" 96 . Na luta pela «pureza» memorial do republicanismo, o discurso médico é cindido pela prédica dos purgatores: na violenta folha editada pelos quintanistas, após o primeiro manifesto Palavras claras, alunos evocam Daniel de Matos, jurando "mais uma vez perante o país, que havemos de promover a consagração solene da Tua memória" ${ }^{97}$, no difuso culto da religiosidade e do milagre médico.

Em pleno ralliement da guerra religiosa, uma portaria surda publicada no Diário do Governo anula o doutoramento do médico Meireles do Souto, autor da tese Lourdes e a Medicina aprovada na FMC em abril de $1924^{98}$. A questão cinde a opinião pública e no conselho facultativo, que aprova a recomendação, Álvaro de Matos (filho de

${ }^{96}$ Cf. id. ib. 5-72; «A história (.)», 73 e ss; $c f .12-13$ e 26; A. S. LAmY, o. c., 219-20; F. Morais, o. c., 107-08.

${ }^{97}$ S. ed., Coimbra, 26 de abril de 1921, col. própria, cl. 2.

${ }^{98}$ Gratos à pista de Maria Rita Lino Garnel. Cf. António de Azevedo Meireles Do Souto (1900-72), Lourdes e a Medicina, Figueira da Foz, Typ. Peninsular, 1923 (anterrosto, 1924); o autor, secretário geral do III Congresso Internacional dos Médicos Católicos (1947), tem vasta bibliografia, Médicos e Santos (ensaio agiográfico) ou O Papa João XXI e a sua obra científica. Na introdução à tese, deseja que "em escritos meus a censura eclesiástica nada tenha que apontar" declarando "não ligar à palavra milagre ou milagroso ou congéneres outro sentido que não seja o popular, deixando à Igreja inteira liberdade de interpretação" e agradece "aos doutos professores" pelo "ensejo da tese sobre assuntos médico-confessionais" [9]. Nas conclusões aclara: “ $1^{\text {a }}$ ) as curas de Lourdes existem; $2^{\mathrm{a}}$ ) (.) nada têm com a histeria; $3^{\mathrm{a}}$ ) (.) são inexplicáveis pela Ciência; e portanto: $\left.4^{a}\right)$ (.) são de ordem extra-natural" [121]. Contra "pretensas explicações científicas", contesta efeitos terapêuticos da Faith -healinge, a «fé que cura» na expressão de Charcot, as psicoterapias puras, a sugestão colectiva, os eflúvios (Beraduc) até o sopro curador das multidões, de E. Zola, apoiando-se em passos didácticos de Elísio de Moura, e imputando a factores «extra-médicos» os factos curativos e as 
Daniel de Matos) exige que seja explicitado o disposto do $\S 5^{\circ}$ do art. $34^{\circ}$ do novo regulamento da Faculdade, a cláusula de salvaguarda: "a aprovação das dissertações não envolve concordância com as doutrinas nelas expostas ou defendidas"99. A cisão entre católicos e «liberais» chega ao Parlamento. No Diário da Câmara de Deputados lê-se que a 8 de maio Torres Garcia, dirigente da Sociedade de Defesa e Propaganda de Coimbra e deputado da área do governo Álvaro de Castro, contesta que no Estado religiosamente neutro se aprove uma tese apologética, com o nihil obstat e o imprimatur do bispo de Coimbra. Lino Neto, teólogo e jurista, presidente do Centro Católico, na sessão de 16 de junho, refere que "segundo uma nota oficiosa publicada nos jornais de ontem, publicou-se uma portaria surda (.) pela qual é desdoutorado da Universidade de Coimbra o Sr. Dr. Azevedo Souto", interpelando o governo pela violação da autonomia universitária e ingerência em assunto estranho à governação.

Na portaria do ministro da Instrução Pública, Hélder Santos Ribeiro, de 12 (publicada a 17) de junho, considera-se que, dada a "inobservância de disposições legais resultou ser admitida [na FMUC] uma tese que não devia ser aceita, como até professores da mesma Faculdade o declararam, posteriormente, em sessão do Conselho, por ser uma tese de natureza puramente confessional" e "absolutamente estranha ao exercício científico da Medicina”. Ao violar expressamente a lei, por não designar as duas cadeiras sobre as quais deveria ser interrogado o candidato nos Actos, "manda o governo da República" que seja "declarado nulo e de nenhum efeito, desde o seu início até à conclusão, o processo do Acto de doutoramento" ${ }^{100}$. Enquanto faculdade ${ }^{101}$ e

capacidades terapêuticas da Gruta (ib., 107-116). Para a notícia do doutoramento com 18 valores - Gazeta de Coimbra, n. ${ }^{\circ}$ 1580, 3-IV-1924, 1, cl. 3.

${ }^{99} \mathrm{Cf}$. Gazeta de Coimbra, n. ${ }^{\circ}$ 1594, 10-V-1924, 1, cl. 3.

${ }^{100}$ Diário do Governo, II série, n. ${ }^{\circ}$ 138, 17-VI-1924, 1943, cl. 1.

${ }^{101} \mathrm{Na}$ moção aprovada a 28 de junho, a Fac. dá por infundada a acusação de inobservância processual e formal por parte do candidato, bem como na constituição do júri, distribuição e marcação de provas; e nos termos do regulamento de agosto de 1911, não considera possível exercer "qualquer fiscalização, crítica ou censura prévia" sobre teses; nem reconhece ao ministro "competência para se pronunciar sobre o carácter e o valor das teses de doutoramento ou quaisquer outras provas", postura "atentatória do prestígio da Faculdade" que "ofende gravemente a autonomia universitária", pelo que repudia "a doutrina do primeiro considerando da portaria” (tese confessional, absolutamente estranha ao carácter científico da 
católicos refutam a decisão, republicanos aplaudem-na: "Ficou assim de alguma forma reparada a afronta feita à opinião liberal do país", pois "com ou sem imprimatur"102 "não põe tolerar-se que um aluno aproveite um acto de doutoramento em medicina (e não em teologia) para uma exibição política retumbante". Para o republicano Despertar ${ }^{103}$ seria como se uma excelente tese de Química fosse aprovada em Direito. Exclusão por falta de comparência: não havia alguma faculdade portuguesa de Teologia para se defender a tese.EÁlvaro de Castro aclara que a "latíssima" autonomia universitária "termina onde começam as prerrogativas do Estado republicano"104. O episódio não ganha maior expressão: as graves rixas da Queima das Fitas, com tiroteios entre futricas, polícias e estudantes, levam à greve e autoexclusão académica em protesto $^{105}$.

Da exclusão em Psicologia Experimental reclama na praça pública em abril de 1928 o ex-docente no Liceu José Falcão (1913), Manuel Serras Pereira ${ }^{106}$, dirigente do movimento de 1919 em defesa da Faculdade, nas Letras assistente de Psicologia geral e

Faculdade) e lavra protesto contra a interferência do ministro - cf. A Medicina Contemporânea, vol. XL, n. . 26, 6-VII-1924, 215.

${ }^{102}$ Souto nega que os 50 exemplares da universidade tivessem o imprimatur eclesiástico, mesmo se por lei o pudesse fazer, mas sim outros que "pôs à venda" - A Medicina Contemporânea, n. ${ }^{\circ}$ 20, 18-V-1924, 158-59.

${ }^{103}$ O Despertar, n. ${ }^{\circ} 742,18-\mathrm{VI}-1924,2$ cl. 3.

${ }^{104}$ Cf. A Medicina Contemporânea, n. ${ }^{\circ}$ 25, 22-VI-1924, 200.

${ }^{105}$ Cf. Gazeta de Coimbra, n. ${ }^{\circ} 1602,29-\mathrm{IV}-1924,2$, cls. 1 e 2; e n. ${ }^{\circ} 1603$, 31-V-1924, 1, cls. 5-6.

${ }^{106}$ N. em 1889 (Alcaravela), assistente de 1-I 1921 a 30-IX-1925, AUC, Processos de Professores, IV, 1 D, - 7-5, n. 206; e Certidões de Alunos. Matriculado em Direito em 1909-10 sem concluir o curso, transita em 1914 para Letras, bacharel em 1920. Terminará a carreira, na década de 1950, como professor do Liceu Passos Manuel.

Do corpo docente da Faculdade, cujo director era Eugénio de Castro e secretário Joaquim de Carvalho, constam M. dos Remédios (bibliotecário da Faculdade, Filol. Rom.), Oliveira Guimarães ( $1^{\circ}$ grupo, Filol. Clássica), Carolina Michaëlis de Vasconcelos ( $3^{\circ}$, Filol. Germ.), António de Vasconcelos, Gonçalves Cerejeira e Paulo Merêa ( $4^{\circ}$, História), Anselmo Ferraz de Carvalho ( $5^{\circ}$, Geografia), Eusébio Tamagnini Encarnação (6 $6^{\circ}$, Filosofia); e os assistentes Simões Ventura $\left(1^{\circ}\right)$, M. dos Santos Gil $\left(2^{\circ}\right)$, Ferrand P. de Almeida e J. Providência e Costa $\left(3^{\circ}\right)$, J. F. Correia Monteiro e J. J. de Brito e Silva $\left(4^{\circ}\right)$, Amorim Girão $\left(5^{\circ}\right)$ e Serras Pereira $\left(6^{\circ}\right)$. Cf. Anuário da Universidade de Coimbra 1921-22, C. ${ }^{\text {bra }}$, IU, 1923,71-73. Alves dos Santos, ausente na acção política. 
Psicologia experimental (1921-25), leitor em Hamburgo de Literatura Portuguesa (1927). Em parangonas delata n'A Voz de Coimbra ${ }^{107}$, jornal "republicano independente e regionalista" 108 , a fraude na acta da reunião ("falsa, ilegal e iníqua") do júri que em 13 de junho de 1925 o preterira no concurso a professor no grupo de Filosofia ${ }^{109}$. Falsa pois o candidato "não foi excluído mas admitido"; ilegal por alegadamente votarem dois professores sem direito a voto; iníqua, "além doutros fundamentos, os dois professores, sendo incompetentes, no ponto de vista legal, eram ainda incompetentes, no ponto de vista científico". A alusão a John Opie ${ }^{110}$, leitor de Inglês, e a Eugénio de Castro, "grande poeta, mau professor e mau colega", que votaram contra, gerava o caso grave, na óptica do excluído, notório acto indigno da Faculdade ${ }^{111}$, tanto que professores não presentes nas provas, como Anselmo Ferraz de Carvalho, se abstiveram. Mas o geógrafo, declara o queixoso, "não entrou no magistério por força dum decreto, pela circunstância de ser poeta, ou de ter nascido em Inglaterra". S. Pereira, escudando-se no voto favorável de Mendes dos Remédios e Simões Ventura e censurando a posição maioritária, reclamava a revisão ou rectificação da votação e a eliminação dos " 2 votos ilegais", única modo de superar a "indignidade" da situação, como o presidente do júri, Remédios, designara a actuação dos pares ${ }^{112}$.

${ }^{107}$ Manuel S. Pereira, «Faculdade de Letras. Um caso grave», A Voz de Coimbra, n. $30,12-\mathrm{V}-1928,6$.

${ }^{108}$ Janeiro-junho, 1928, José Brandão Pereira de Melo (dir.). Não confundir com Voz de Coimbra, de 25-V-1924 e 26-IX-1925, relevantes as crónicas antiparlamentares de Adriano Vieira Coelho, um dos redactores do programa mínimo do golpe de 1926 in LuIS BIGOTTE CHORÃo, «Em torno do 'programa' do 28 de Maio», Luís Reis Torgal (ed.) O 28 de Maio Oitenta Anos Depois, Coimbra, CEIS20-ITHI, 2007, 19-25); F. PINTO LoureIro, Jornais e revistas do distrito de Coimbra, Coimbra, BMC, ed. CARNEIRo DA Silva, 1947, 136-37.

${ }^{109}$ A 6-I-1925, Remédios propõe no Senado a abertura de concursos já previstos e adiados, para os $3^{\circ}, 5^{\circ}$ e $6^{\circ}$ grupos, dado existirem candidatos a esses concursos, sem dúvida pensando em Serras Pereira, o único ao $6^{\circ}-A U C$, Livro de Actas do Senado, n. ${ }^{\circ} 3$, (1925-1929), mns. sem cota, $f$. $2 v$.

${ }^{110}$ John Opie (1864-1936), destacado guia espiritual de pequenos grupos cristãos anorgânicos, activos nas áreas de Coimbra e Aveiro.

${ }^{111}$ M. Serras Pereira, "Faculdade de Letras...", A Voz de Coimbra, n. . 25, 25-IV-1928, 4, cl. 1.

${ }^{112} I d ., i_{b}$, n. $^{\circ} 27,2-\mathrm{V}-1928,8, \mathrm{cl} .4 ;$ e, n. ${ }^{\circ} 29,9-\mathrm{V}-1928,8, \mathrm{cl} .1$. 
Reclamava contra a "inutilização" de "nove anos de trabalho honesto" 113 , currículo equiparável ao do antigo condiscípulo em Direito, Joaquim de Carvalho (imagem do capital intelectual que este aforra ${ }^{114}$ ), caso típico do que chama, repetindo, o "18-19": aprovado com 18 valores na licenciatura e 19 no doutoramento, distinto na Escola Normal Superior, alega "proficiência notável" na docência no liceu José Falcão, dando "mais provas experimentais de competência pedagógica" que muitos dos opositores ${ }^{115}$ : a sua bibliografia era penhor do mérito científico em Psicologia experimental ${ }^{116}$ em cuja regência fora avaliado pela Faculdade com "proficiência notável". Assim, fora "condenado pelo capricho e pelo ódio" "117. Regressado da Alemanha em 1927 achara as portas fechadas e apesar de Remédios propor a admissão,

${ }^{113} I d .$, ib., n. ${ }^{\circ} 27,2-\mathrm{V}-1928,8$, cl. 1.

${ }^{114}$ A 31-VII e 21-X de 1925, Carvalho quer procurar "um professor de Psicologia, por intermédio do prof. Dumas de Paris" para "Psicologia Experimental e a direcção do respectivo Laboratório" - Actas da Faculdade de Letras, vol. II (1925-1936), C. a, AUC, 1991, 30-31, mas chama-se o médico Maximino Correia. No processo individual do assistente S. Pereira arquiva-se o ofício de resolução não assinado (datado de 18 fevereiro 8): "constituída a Faculdade em júri no concurso para provimento das vagas de assistente e verificando que o único concorrente era o Doutor Manuel Serras Pereira, em virtude de determinados documentos apresentados pelo Presidente [Castro], logo os vogais do Júri, por Unanimidade se declararam moralmente impossibilitados de tomar parte em qualquer acto relativo a este concurso" - AUC, Processos de Professores, IV, $1^{\mathrm{a}} \mathrm{D},-\mathrm{7}-\mathrm{5}, \mathrm{n} .^{\mathrm{o}}$ 206, pasta $R Z-2$. Em ofício à reitoria, o director da Faculdade esclarece que houve provas do concurso (arquivam-se os pontos do exame) a 12 e 13 de junho. Reprovado em conselho, Pereira anexara registos de bom comportamento cívico, moral, criminal e militar - AUC, U. C. Reitoria. Correspondência da Faculdade de Letras (.), IV, 2C, - 11- 5, 1 .

${ }^{115}$ A Voz de Coimbra, n. ${ }^{\circ} 33,19-\mathrm{V}-1928,8, \mathrm{cl} .3$.

${ }^{116}$ Id., ib., n. ${ }^{\circ} 30,12-\mathrm{V}-1928,6$, cl. 1: Possibilidade do método científico em Psicologia; Tese escolástica do composto humano; Função da análise quantitativa em Psicologia experimental; Estudo dos fenómenos espiritistas e sua interpretação científica; Imagem e pensamento e anuncia que prepara a tese sobre $« \mathrm{O}$ valor da escolástica». Conferencista sobre espiritismo no liceu José Falcão (Gazeta de Coimbra, n. . 1990, 8-I-1927, 1, cl. 2) e Universidade Livre, interpreta-o à luz da psicologia "experimental", não "espírito desencarnado" (ib., n. ${ }^{\circ}$ 1992, 13-I-1927, 1,cl.2). Em 1930 é director (com E. Sanches da Gama, Sílvio Pélico, Costa Pimpão) do jornal desse Liceu, O Brado Académico, escrito por Políbio G. dos Santos, Salvador D. Arnaut ou Alípio Rocha.

${ }^{117}$ M.S. Pereira, «Faculdade de Letras...», A Voz de Coimbra, n. ${ }^{\circ} 33,19-\mathrm{V}-$ $-1928,8, \mathrm{cl} .4$. 
o conselho chumbara-o, persistindo a minoria (O. Guimarães, E. de Castro, J. de Carvalho e S. Ventura) na recusa para qualquer cargo que não fosse assistente. Acusa de novo, na segunda via, a Faculdade de Letras de "mentir" quanto a "critérios de escolha e selecção nos concursos" 118 . O "condenado" sente-se "injustamente afastado" na "luta contra uma corporação"

Pereira reajusta depois a estratégia discursiva, interpelando o ministro da Instrução e alvejando o já liquidado Oliveira Guimarães na referida obra A questão de Coimbra. Ao evocar o episódio, conta obter dividendos na minoração intelectual do ex-reitor; acusa-o de exultar as invasões francesas no tributo honoris causa ao marechal Joffre e dizer palavras "atentatórias ao patriotismo": "Napoleão trouxera a Portugal, nas dobras da sua bandeira, os emblemas da liberdade, igualdade e fraternidade" 120 , indício por António Coelho explorado na Questão de Coimbra, mas sem o "discurso fradesco" que então se apusera ao reitor $^{121}$. As vias argumentativas de Serras Pereira não são doutas. Diz-se lesado pelo teor de declarações num documento exarado pela Polícia de Informações, do qual afirma ter apresentado memória ao director da Faculdade para que este a enviasse aos ministérios do Interior e Finanças, mas não explicita que motivo esteja na base da alegada prova e a narrativa do episódio é nebulosa ${ }^{122}$ nem há rasto documental (i. e., terá sido o documento lido no conselho por E. de Castro). Em suma, alega que prevaleceu contra si a "divergência de ideais filosóficos", mas tanto invoca a ética kantiana ("a mentira do progresso das ideias morais", pois, no fundamento teórico, qualquer reconheceria que "Darwin, Spencer e Guyau nunca poderão, no progres-

${ }^{118}$ Id., ib., n. ${ }^{\circ} 35,30-\mathrm{V}-1928,6$, cl 1. Remédios fora consultar o ministro da Instrução sobre o "assunto melindroso" do provimento do oponente único ao concurso do $6^{\circ}$ grupo - Actas da Faculdade... II, o. c., 111.

${ }_{119}$ Apud A Voz de Coimbra, n. ${ }^{\circ}$ 37, 6-VI-1928, 8, cl.s 2 e 3; e n. 36, 2-VI-1928, 8, cl.s 1-3.

${ }^{120} C f$. M. S. Pereira, A Voz de Coimbra, n. ${ }^{\circ} 39$, 18-VI-1928, 8, cl.s. 1-2; e n. ${ }^{\circ} 42,23-V I-1928,4$, cl.s 2 e 3.

${ }^{121}$ António Coelho, A questão de Coimbra o. c., 67 e ss.

${ }^{122}$ M. Serras Pereira, "Faculdade de Letras...", A Voz de Coimbra, n. . 35, 30-V-1928, 6, cl. 4. 
so moral, transcender Kant e Juvalta") como assume, no oposto trilho, a "troca de trabalhos com o grande António Sardinha" 123.

Sem revelar a dita "inversão da consciência moral dos Catões" da faculdade e o "crepúsculo moral da consciência" universitária, Guimarães nega imputadas afirmações nos Actos honoríficos de Joffre, "por ter sido publicado o texto, se pode ver que nenhuma das aludidas declarações foi proferida". Ao insinuar insanidade do antagonista, encerra a polémica, e encerra-se o jornal ${ }^{124}$, que Pereira movera ao longo de meses, pois "as pessoas que, como eu, algo sabem de psicologia mórbida" apercebiam-se da loucura na "forma mais inconsistente e contraditória" da expressão do opositor que só merece "sorriso de piedade" 125 . Desforrado do público diagnóstico psiquiátrico a que fora sujeito em $1921^{126}$, o polémico Guimarães, conservador, móvel ${ }^{127}$, anatematiza o adversário. A argumentação evidencia o triunfo retórico dos manuais de psiquiatria e psicanálise como estratégia de convicção / destruição em polémicas e indício de autoridade científica nas purgas universitárias.

Serras Pereira defendera formalmente a primeira dissertação em «Psicologia experimental» no país, A tese escolástica do composto

\footnotetext{
${ }^{123} I d ., i b .$, n. $^{\circ} 27,2-\mathrm{V}-1928,8, \mathrm{cl} .4$.; e Id., ib., n. ${ }^{\circ} 32,19-\mathrm{V}-1928,3$, cl. 4.

${ }^{124} I d .$, ib., n. ${ }^{\circ} 33,23-\mathrm{V}-1928,8, \mathrm{cl} .3$.

125 Oliveira Guimarães, «Desmentido categórico», A Voz de Coimbra, n. . 47,
} 27-VI-1928, 4, cl.s 2-3.

${ }^{126}$ A. CoElho (o. c., 62-63) diagnosticara em Guimarães um psiquismo "semelhante ao do homem selvagem primitivo", agravado pela "ausência de sentimentos morais" e "perversão de personalidade": "A perversão dos sentimentos filiais" e "imoralidade de transportar a amante para uma das tribunas da Sala dos Capelos numa sessão soleníssima e altamente patriótica, acusam uma debilidade moral sem rebuços". Sofria de "linguagem desembestada de velha regateira", "delírio de grandeza", "hipertrofia da personalidade", "alucinações auditivas", "amnésia": "seria possível ainda - hoje que o delírio freudiano vai atormentando muita gente -, se se fizesse uma psico-análise a este homem, encontrar-se qualquer aberração psíquica de origem sexual".

${ }^{127}$ Dando em 1927 falida a via demoliberal, contra "oligarquias criadas artificial e artificiosamente", avoca a representação orgânica para "garantir a selecção por via natural, verdadeiramente biológica, de uma genuína elite dirigente, sem a qual não há governo possível". Apreciado por Salazar, elabora o projecto de reorganização do ensino público que suprime a Faculdade de Letras do Porto, a que o ministro das finanças acede - [OLIVEIRA GuIMARÃES], «Da errónea concepção da "élite" em Portugal (.)», Arquivo Pedagógico, v. I, n. . 1, março, 1927, 80-87. 
humano (1923), depreciada no posterior concurso por não versar psicologia experimental, citando apenas marginais, parcos dados empíricos obtidos em segunda mão, numa dúzia de páginas, notam Ferreira Gomes e Costa Pinto ${ }^{128}$. De facto, é deserto empírico: pobre no dispositivo bibliocrítico, timbre à época, ausente a riqueza reflexiva, metodológica, terminológica avançada por Sílvio Lima (1928), a tese agencia validar a escolástica superioridade da alma sobre o corpo, testando-a na "insuficiência idealista, na insuficiência materialista, na psicologia experimental e na bergsoniana Matiére et Mémoire" 129. Ao arrepio da autonomia epistémica da Psicologia, sugeria assim o retorno às teses teológicas coimbrãs do século XIX que, ao recusarem ao cogito o estatuto de "secrecção" ou função cerebral intuíam-no como movimento dependente de "uma causa immaterial, como a alma humana ou como o primeiro motor - Deus" ${ }^{130}$. E se conciliavam alguns, no ocaso do centénio, saberes científicos e revelação católica, desdramatizando o conflito escatológico, dando à ciência o papel de "sacerdotiza da Divindade no grande templo da natureza: e vem a ser esta a sua missão mais nobre, a cupula do edificio da sua gloria" 131 - perdia-se a lição.

A "alma humana tem por natureza informar a matéria - as informações e principalmente a consciência são posteriores do acto essencial de informação" é um re-enunciado do juízo aristotélico. A partir de Bergson, sem qualquer referência empírica ou inferência da observação, no caso de "trepanações enormes da massa encefálica" deduzia a "independência do espírito" 132 . As intuídas trepanações enormes anulam a via empírica e experimental: Phineas Cage, não está lá. A tese versa,

${ }^{128}$ Apud AmÂnCIO DA Costa PINTO, «Estudos de memória humana na década de 1920 na Universidade de Coimbra», Psychologica, Revista da FPCEC, n. ${ }^{\circ}$ 9, 1993 , 14 , nota 8 .

${ }^{129}$ Manuel Serras Pereira, A tese escolástica do composto humano, Coimbra, Imp. Académica, 1923, XIII.

${ }^{130}$ José Maria Rodrigues, Pensamento e Movimento. Estudo Histórico-Crítico sobre o materialismo contemporâneo, Coimbra, 1880; id., A Faculdade de Teologia e as doutrinas que ela ensina, Coimbra, 1886; M. . Fernanda Figueira, «A Faculdade de Teologia perante o Materialismo (1861-1905)», o. c., 223-30.

${ }^{131}$ António de Vasconcellos, Sciencia e Fé (discurso na Real Capela da Universidade), Coimbra, 1887 (cf. O Instituto, XXXVII, n. . 8, II-1890; 493-504);

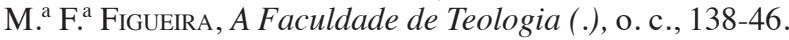

${ }^{132} C f$. Manuel Serras Pereira, A tese escolástica do composto humano, o. c., XIII e 23. 
se for lícita, teologia intuicionista antem experimental ou psicologia perene, mediada pelo espírito de cruzada que exautora o agnosticismo "ultra-solipsista"133: "a pretensão positivista ou agnóstica é uma ignorância filosófica monstruosa e evidencia o profundo acriticismo dos cépticos contemporâneos" ${ }^{134}$, escreve o psicólogo neotomista. A tese fora aprovada com 19 valores ${ }^{135} .1^{\circ}$ arguente: O. Guimarães, eclético positivista, darwinista na "galeria dos mais curiosos e pittorescos typos nacionaes" (Livro do Doutor Assis); arguido, intuicionista de orientação conciliar, persona non grata na academia ${ }^{136}$. A exclusão evidencia, pela negativa, a tensão entre as matrizes «teológica»e «científica» das Letras: arguido e arguente da tese de 1923 tematizam a teologia não a psicologia. É como argumento, pouco racional e sob o signo da querela escatológica, que a Psicologia entra na esfera pública e na primeira e indecisa configuração universitária. Primeiro, entre Alves dos Santos e "despeitados e cabotinos" reaccionários da Faculdade ameaçada de extinção; depois entre Serras Pereira e o "ex-padre, ex-monárquico e ex-sidonista" Guimarães. A alma cauciona o expurgo. Entende-se: a linguagem psiquiátrica legaliza e apropria-se do discurso da expulsão; pensamento é terreno «sagrado».

Serras Pereira visava o espaço vazio da ciência nova que urgia na actualização científica e epistémica agendada pela faculdade. No preciso momento da querela, primavera de 1928, regressado do cantão genebrino de Rousseau e Claparède, concluía Sílvio Lima O Problema da recognição, autenticada hoje pelos especialistas como pioneira tese de doutoramento em Psicologia Experimental exposta e defendida numa universidade portuguesa, em Coimbra. Admita-se

${ }^{133} \mathrm{O}$ agnóstico imobiliza o pensamento num "alogismo hiper-solipsista", $c f . i d ., i b ., \mathrm{X}$.

${ }^{134}$ Cf. id., ib., X-XI. Cf. id., Deus como primeira intuição e último conceito em Filosofia, Coimbra, Biblioteca Geral da Universidade, Cursos e Conferências de Extensão Universitária, XXIV, 1936.

${ }^{135}$ AUC, Faculdade de Letras. Doutoramentos (Livro de actas), mns. fl. 18. Atribuição de insígnias: 9-XII-1923.

${ }^{136}$ N'O Ponney, Castelão de Almeida relata (V,n.o 109, 9-II-1935, 1) a queda da torre de Santa Cruz "que Portugal inteiro adorava e que tanta miséria escondia ... foi um ar que lhe deu, tumba!...caiu com galo e tudo!". E o "Dr. Serras Pereira para não ficar atrás da atitude tomada pela velha torre e porque as suas atitudes foram sempre tomadas no espírito de solidariedade...catrapuz! Caiu ao mesmo tempo!..."-sub. ns. 
o cenário emocional, entre parangonas e a guerra aberta nos jornais, em que se inscreveu para finalizar a dissertação científica cujo objecto outros, desde o divino Platão, chamavam alma.

\section{Da teologia da intolerância à ideologia da exclusão: o caso Sílvio Lima}

Se a Filosofia não se anula por estimativa oficial, não é também o último acto de uma Tragédia previamente (de)cifrada: "Os sofistas, obscura ou claramente interessados na defesa de qualquer espécie de tirania, acharam sempre oportuno afirmar que a liberdade é um conceito vazio de sentido", anota Lourenço em 1949: "Aterrorizados mentalmente com a extensão de grandeza implicada no seu exercício, preferem negá-la. Mas nenhuma tirania foi jamais suficientemente honesta ou forte, para confessar em público aos seus súbditos que eles não são livres" ${ }^{137}$. A exclusão do psicólogo e filósofo Sílvio Lima permitirá extrair duas ilações capitais: a mediata traduz o reforço dos «sofistas» nos estudos humanísticos e no ensino universitário; a imediata esclarece até que ponto, no caso singular, o ditador teve de assumir, ao nulificar resistências intelectuais, como o poder civil do Estado se estrutura num catolicocentrismo que expulsava a essencial libertas philosophandi, livre escrita, ensino e investigação filosófica, subjugando-a ao exame prévio e à censura política e pessoal.

Discípulo cívico e intelectual (1904-1993) de Joaquim de Carvalho e António Sérgio, licenciado em Filosofia, o único em 1927, com a tese Ensaio sobre a ética de Guyau nas suas relações com a «crise moral contemporânea», excurso na refutação metafísica do filósofo francês (L'Irréligion de l'avenir e Essai d'une morale sans obligation ni sanction) à dominante concepção teológica da moral, Sílvio Lima ao postular a secularização ética, a kantiana «ciência da liberdade», no capital axioma da razão autónoma, livrando-se do sociologismo positivista e das paralaxes cientistas que asfixiavam a filosofia, situa a ética no horizonte da "realidade e idealismo", ao suspender "a moral de um fio de luz divina" e ata-a à "vida, à realidade social".

${ }^{137}$ Eduardo Lourenço, [1949] Heterodoxia I, Lisboa, Gradiva, 2005, 27. 
A irredutibilidade do cogito e da vida no chão fértil e plural de "mónadas que pensam diferentemente" e a consciência correlacional do relativo numa filosofia da consciência crítica -, conduzem-no à livre consciência e à adogmática liberdade religiosa ${ }^{138}$. A tese de doutoramento, $O$ problema da recognição (1928) - orientada na Suíça por Claparède, mestre dos estudos psicognitivos, em contacto com Heléne Antipoff (e Paul Godin, Jean Piaget), influída em parte por Piéron em Paris - refuta a matriz fisiologista, materialista e positivista do psiquismo, melhor, a dessubjectivação do psiquismo e o isolacionismo fenoménico que o modelo psicofisiologista de Wundt encarna. O complexo estudo do reconhecimento e memória, epicentro epistémico das psicociências, era contudo íngreme vereda por ser milenarmente trilhada pela teologia e pela filosofia: seria essencial libertar o estudo psicológico da memória do quadro da teologia dogmática e de estéreis tentativas (espiritismos em voga, gnosticismo de várias matizes) e mesmo da especulação filosófica de modo a não cair doutro lado no mero epifenómeno social ou dado biológico, como denunciava na inábil matriz positivista do sociologismo e no materialismo estreito. O resultado, confrontado com Matiére et mémoire de Bergson, é achar a mancha afectiva na memória, sentimento intelectual omitido pelo racionalismo, intelectualismo e positivismo «frios»; contra a teoria imagética reconstitui na mnesis o sentimento de identidade pessoal (Maria Salomé Pinho, Psychologica, 1993), senão é ela mesmo reconstituinte. Arrojada tese, no palco maniqueu alma /cérebro: a psique não é mera síntese biológica de processos orgânicos ou metampsicosis de uma alma no mundo; e nem se confina à consciência - seguindo Jung nas «psicologias da profundidade», não a cede sem cláusulas ao freudiano reino pulsional da libido e do destrudo, mitografia irracionalizadora, a seu ver.

São úteis estas notas. Em 1930, o antigo mestre, agora cardeal Cerejeira, promove a $3^{\text {a }}$ edição de A Igreja e o pensamento contemporâneo, texto que Lima já anotara criticamente na sua tese de licenciatura, libelo contra o cientismo materialista e monista que o discurso positivista e anticlerical repisava, em ordem a afirmar a supremacia da religião sobre o conhecimento e da Fé sobre a ciência. Num texto de refutação

${ }^{138}$ Sílvio Lima, Obras completas [OC], (ed.) José Ferreira Da Silva, Lisboa, F. C. Gulbenkian, vol. I, 2002, 155-58; Cf. a citada tese Sílvio Lima, um místico da razão crítica, IV parte, $391-463 ;$ II $^{\text {parte }}, 176-260$. 
filosófica, Notas críticas (.), e no rasto da polémica de Almeida e Paiva (Liberdade, Ciência e Religião, 1929), Sílvio Lima contesta o «retorno do pensamento» à Igreja», em termos cordatos e esclarecidos, mas não deixa de denunciar, em sólida hermenêutica historiográfica e filosófica, debilidades argumentativas do mestre e carência de legitimidade para reeditar, como prelado, um texto apologético sob a capa de mestre universitário. Da critica ressalta a incapacidade dialógica e escasso pluralismo intelectual do «texto de combate» do antagonista, mais atreito a avocar a auctoritas religiosa, no momento da reconstrução ultramontana do neotomismo, do que a esclarecer o livre munus da ciência. À revelia do Cardeal, Lima propunha uma visão diacrónica do miraculoso, de ordem integradora e racional, contra a cega convicção da sua afirmação ou liminar negação.

A pública exposição origina a avalanche dos protestos católicos. Em meses, livro e sobretudo o autor, na última grande disputa religiosa até 25 de abril de 1974, são alvos privilegiados da artilharia pesada da Reconquista Cristã (Correio de Coimbra, Novidades, Nação Portuguesa, Estudos); do Instituto Católico de Paris, mons. Baudrillard, vem a Coimbra exautorar o cepticismo («Ciência e Religião», 19-II-1931); na Academia das Ciências de Lisboa, católicos e mações debatem limites da ciência e seus poderes. Nos jornais adversos o tom de acusação a Lima recrudesce: ímpio, mação, soberbo, incapaz universitário. Na réplica Sílvio Lima arrasa o teólogo opositor, Trindade Salgueiro, autor de Um livro infeliz, que o sentencia depois: Lima, «infeliz autor», «descarrilara», perdera a razão. É a fermosa estrivaria do «santo ódio teológico»: à crítica sucede a agressão desembestada. A devassa insinua-se em páginas teológicas, vasculha almas. Purgatores atacam o professor de filosofia. A cremação rescalda no verão de 1931. Ultramontanos e corporativos não esquecerão a afronta do pensador livre; e livre-pensadores menos lhe relevam a insubmissa autonomia, embora táctica e conjunturalmente favorável. Adverte-o Costa Pimpão, condiscípulo, republicano católico: Lima está entre Cila e Caribides lugar inabitável nestas latitudes, não-lugar como se quer fazer crer.

No início de 1935, Sílvio Lima lança O Amor místico, tese de concurso que não chega a arguir. Minuciosa reflexão sobre o Amor e o Misticismo, apresenta uma leitura crítica e post psicanalítica ao sexualmonismus e panlibidismo freudianos e às suas reduções de uma antropologia religiosa, patenteando insuficientes hermenêutica e 
domínio diacrónico e conceptual do autor de Totem e Tabu. Ao atender à técnica mística das gnoses orientais, no exame da dupla ambiguidade da linguagem amorosa e da linguagem mística e religiosa, Lima faz a genealogia das cosmogonias da sexualidade, carnais representificações de pactos místicos entre Eros e Mistério, Amor e Deidade (excelentes excursos à teopornia e prostituição sagrada, rituais regeneradores e soteriológicos dos enterros das sementes, misticismo orgiástico, cultos sexolátricos). A crítica à repressão erótica e sexual movida pela tradição cristã (Bataille décadas depois, ignorando o texto coimbrão, segue o original sulco mas em direcção ao misticismo ateu), lê-se em capítulos de grande fôlego, na ofensiva dogmática e prática contra o sexo, a mulher e o amor erótico (nudez, pudor, mariologia, interdição da educação sexual, celibato dos padres, etc.), estribados em densa erudição, domínio de fontes e exemplar hermenêutica. Valorações elaboradas do amor (Max Scheler), não se restringindo à genitalidade ou sexualidade, denunciam debilidades - a ausência do amor livre e da liberdade erótica - na teoria pulsional freudiana (que Lacan evidenciará em 1960 e 70) e conduzem Lima ao apólogo da filosofia à maneira de Platão e ao espinosiano amor intellectualis ad Dei. A opinião católica não discute o livro, é apreendido; e o autor será expulso, proibido de leccionar em qualquer grau e escola.

\section{O expurgo ideológico como exorcismo do Mal}

Neste case studied, a constelação de interditos e expurgos correlata da crescente inutilização da Universidade pela autocracia, polariza-se em 1935. À repressão dos movimentos estudantis ligados à resistência republicana, de 1928, o putch fracassado de 20 de julho ${ }^{139}, 1930$ (a tomatada nos Capelos e a greve ${ }^{140}$, ao remeterem para o paradigma de 1862

${ }^{139} \mathrm{Na}$ greve de 1926, liderada pelos alunos de Letras Sílvio Lima e Paulo Quintela, alargada às academias do país, cindindo estudantes e interesses universitários e politécnicos não se manifesta a autoexclusão.

${ }^{140} \mathrm{Na}$ greve estudantil, correlata da reorganização do CRA, apoia a manutenção da FDCSI: em 1930, Coimbra é invadida por forças militarizadas e militares (do Regimento de Cavalaria 8 de Aveiro) e no confronto verificam-se três feridos. O governador civil expulsa da cidade os estudantes que foram excluídos por faltas CRISTINA FARIA, As lutas estudantis contra a ditadura militar (1926-1932), Lisboa, 
pressionam a demissão em dezembro de 1930 do reitor Fézas Vital ${ }^{141}$ ) e 1931, seguem-se as purgas de 1947-48. E as duas vagas dos anos 60 , no contexto da guerra colonial, expurgam sobretudo estudantes ao contrário das anteriores. Após o golpe militar de 28 de maio de 1926 e a derrota das insurreições revolucionárias de 1927 e 1931, inspiradas pelo reviralho; desde 1928-1930 e, sobretudo, julho de 1932, Oliveira Salazar controla o conselho de ministros e a máquina politico-ideológica do Estado, na imposição «orgânica» a uma sociedade diminuída nos direitos cívicos e políticos, intelectuais e de livre expressão, associação e manifestação.

Constitucionalizada (1933), a ditadura consolida a hegemonia política e pessoal do «presidente do conselho» no aparelho burocrático, policial-militar e reforça a vigilância sobre o funcionalismo público, tolhendo Oposição e sectores descontentes e golpistas do 28 de maio: a "mentalidade nova" que "fará ressurgir Portugal"142, lança organizações paramilitares e férreo controlo das forças armadas; o Estado Novo desencadeia novo pico de violência persecutória política e social em 1935, tornando-o fenómeno estrutural, estrangulando liberdades, banindo formações sindicais e partidárias, impondo a polícia política e tribunais especiais e arbitrárias medidas policiais e prisionais de «excepção», culminando na criação em 1936 do campo de concentração do Tarrafal e no definitivo lançamento, após testes falhados, das organizações de massas. Inspirado na doutrina social da Igreja (Rerum novarum, 1891 e Quadragesimo anno, 1931) e no programa do Integralismo Lusitano (1914), instaurado com a Constituição e o Estatuto do Trabalho Nacional, reflexo da Carta del Lavoro do fascismo italiano o corporativismo verticaliza funcional e organicamente o exercício profissional dos serviços e actividades económicas, sociais e culturais, como as universidades, capitalizadas pelo Estado nacionalista, totalizador, holista para o combate antiliberal, antidemocrático e anticomunista.

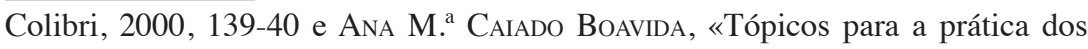
estudantes republicanos», Análise Social, XIX, 1983, 743-56.

${ }^{141}$ CRISTINA FARIA, o. c.,155-58.

${ }^{142}$ Oliveira Salazar, introdução a António Ferro, Salazar, o homem e a sua obra, Lisboa, ENP, 1933, XLI. 
De «transitória» e militar a ditadura passa a definitiva e militante: e medidas excepcionais a habituais ${ }^{143}$. A «nota oficiosa» publicada nos jornais dois dias após esmagar a revolta sindicalista e a CGT, a 20 de janeiro de 1934, dava conta que "foi decidido promover a demissão dos funcionários públicos civis e militares que professem ideias cuja propaganda é prevista e punida pelo decreto $n .^{\circ} 23.303$, não podendo ser nomeados de futuro para cargos públicos os indivíduos que não dêem segura garantia de defender os princípios fundamentais da organização social consignados na Constituição da República", o mesmo se aplicava a promoções ou "a qualquer acesso ou melhoria de situação". O recesso autoritário acentuou-se assim entre 1934 e sucedem-se as aniquilações do nacional-sindicalismo em setembro de $1935^{144}$ e, à esquerda, da organização do Partido Comunista, quase inactivo na hostil conjun-

${ }^{143}$ A autocelebrada "revolução nacional" salazarista não é uma revolução permanente mas prolongado triunfo dum regime de excepção, i. e., de uma «ordem jurídica» que ao manipular a Lei abate os direitos fundamentais. Ora, é um regime de excepção do direito. Este o justo sentido que Sílvio Lima, em texto mais aberto publicado na Revista do Brasil (1940), lia no regime do «autoritarismo»: "o direito faz-se opressão, tirania, pessoalismo, quer dizer, decapita-se, anula-se a si próprio", a sua autoridade é irrespeitável porque "principia por «desrespeitar» os seus concidadãos, reduzindo-os a simples autómatos servis, «robotes» sem alma e sem carne viva, numa só palavra, a coisas e objectos" ( «Liberdade e autoridade, licença e autoritarismo», OC, II, 1670-71).

Ora, uma leitura andoxográfica, v. g., do art. ${ }^{\circ} 8^{\circ}$ (Título I) da Constituição de 1933, deprecia a sistemática violação dos direitos fundamentais por um Estado que (dis)punha a mais elementar cidadania em estado de sítio. Em reclusão domiciliária, melhor, agravada por repetidos mecanismos reprodutores de mentalidades e culturas, washbraining em águas mornas, que colocavam em estado de reclusão domiciliária o sentido crítico individual - o detective das palavras (Augusto Abelaira) - quer a sua expressão no espaço público, quer a sua «apropriação» por uma livre, autêntica e autónoma opinião pública. Com a designação de «estado de direito não democrático», Jorge PaIS DE Sousa («O Estado Novo perante o 28 de Maio e o fascismo» in L. ReIs torgal (ed.) O 28 de Maio oitenta anos depois, Ceis20-IHTI, 2007, 108), oblinula o repetido facto de serem Tribunais, sobretudo plenários, instrumentos de crimes judiciais premeditados e perpetrados contra a liberdade e consciência dos cidadãos, os utensílios da política difusa de intimação e terror, que só o estranho alheamento de instrução criminal da sua actividade, após a revolução democrática, dá sentido - na lógica do funcionalismo que achou subterrâneas (de) pendências para se autoilibar (relevante: HANNAH ARENDT, Responsabilidade e Juízo, Lisboa, Dom Quixote, 2007, m., 30-42).

${ }^{144}$ Cf. António Costa Pinto, Os camisas azuis. Ideologia, Elites e Movimentos Fascistas em Portugal. 1914-1945. Lisboa, Ed. Estampa, 1994, 261-65 e 267-68. 
tura peninsular ${ }^{145}$ confirmada pela derrota das forças da República na guerra civil espanhola em 1939. Ao mesmo tempo, em iniciativas legislativas, o regime tentava liquidar organizações secretas e o Grande Oriente Lusitano Unido - com o dec. n. ${ }^{\circ}$ 1901, a «lei Cabral», nome do deputado católico, monárquico e ex-camisa azul ${ }^{146}$, "dominicano" cuja tarefa "se integra, em natureza, como em conteúdo, nas melhores tradições dos Inquisidores", na expressão de Pessoa ${ }^{147}$. O parecer da Câmara Corporativa integra a legislação antimaçónica nas "melhores tradições" da Itália fascista e da Espanha de Primo de Rivera ${ }^{148}$. Embora se discuta o «Projecto de Lei n. ${ }^{\circ}$ 2» já no início de 1935 , a aprovação na Assembleia Nacional coincide com o decreto da expulsão coerciva da função pública ${ }^{149}$ - sem aparentes reacções no núcleo duro maçónico

\footnotetext{
${ }^{145}$ Cf. Fernando Rosas, O Estado Novo. 1926-1974, História de Portugal, J. Mattoso (ed.), s. 1, Círculo de Leitores, 1994, VII, 235-41.

${ }^{146}$ José Cabral (1885-1950), Advogado, ex-integralista e nacional-sindicalista, deputado e dirigente da União Nacional (1935), seria director-geral dos Serviços Jurisdicionais de Menores, e dos serviços de acção social e política da Legião Portuguesa, depois administrador de empresas públicas.

${ }^{147}$ Fernando Pessoa, «Associações secretas», Diário de Lisboa, n. ${ }^{\circ} 4388$, 4-II-1935, Da República (1910-1935) (ed.) JoEl Serrão, Lisboa, Ática, ${ }^{\mathrm{r} p 2010,} 22$. Sobre o artigo admitiu o poeta ao jeito anarquista: "Pela primeira vez na vida fabriquei uma bomba" - (ib., 419); cf. José BARRETo, «Fernando Pessoa, o Estado Novo e a Igreja Católica», A Igreja e o Estado em Portugal, Norberto Cunha (ed.), Famalicão, CMF - MBM, 2004, 167. A tentada extinção ou contenção da Maçonaria em 1935 é o reverso da militância católica e integrista no aparelho do Estado Novo. Questões essenciais postas por ANTónIo BARRETo (Dicionário de História de Portugal, IX, m. 339-42), continuam sem resposta historiográfica: a não haver cisão, sobretudo post 1929, como OLIVEIRA MARQUES (1933-2007) avocara em A Maçonaria e o Estado Novo, Lisboa, Dom Quixote, ${ }^{2 \mathrm{a}} 1983$, como compatibilizar a militância pessoal e política de mações no Estado Novo (Carmona, Albino dos Reis, Bissaia Barreto, Lopes Mateus, Manuel Rodrigues, Sarmento Rodrigues, Linhares de Lima) com a repressão à Maçonaria (GOLU).

148 Sociedades Secretas. Com um prefácio do Dr. José Cabral, Lisboa, Editorial Império, s. d. [1935], 44-54: e A. H. OliveIra MARQues, A Maçonaria e o Estado Novo, o. c., 257 e 261.

${ }^{149}$ Lei n. $^{\circ} 1901, D G$, n. $^{\circ} 115$, Isérie, $21-\mathrm{V}-1935$, unanimemente aprovada na Assembleia (faltam 13 deputados, 8 justificariam a falta, exprimindo voto favorável; dos absentes é notório Diogo Pacheco Amorim, ultramontano íntimo de Salazar no CADC. Mação, Carmona adoecera (politicamente, pergunta-se), aquando do debate legislativo - Franco NogueIra, Salazar, II, Os tempos áureos (1928-1936), Coimbra, Atlântida (1977), 321-22.
} 
em torno do ditador (Caeiro da Mata, Bissaia Barreto, José Alberto dos Reis, já desquitado, Albino dos Reis) nem a Carmona e aos militares ${ }^{150}$. Salazar ao criar uma ideologia do expurgo, reforçando doutro lado no ensino e na sociedade «apolítica» o peso da Igreja, ia "limpando o terreno de todos os elementos cuja atitude doutrinal não fosse de si defesa contra a invasão" da barbárie comunista, guião para limpar o campo demoliberal, alfobre de espíritos «cheios de ilusões» de paz e justiça, definira-os no discurso premonitório da vaga repressiva da função pública, a 27 de abril de $1935^{151}$. A par da propaganda e da política do espírito Salazar impunha, por via legislativa, total jugo sobre agentes da administração pública, mormente sobre escolas dos diversos graus de ensino, usando expedientes que assegurassem a "unidade moral" e a "ordem jurídica da Nação", avançando na depuração que a ditadura militar iniciara entre 1926-1932 e instituindo o princípio de iure de interdição político-ideológica do acesso a cargos e funções públicas, consolidando o monopólio, de facto e de «direito», de cargos e funções ${ }^{152}$, do qual era único ou último decisor. O biógrafo oficial adita, em termos conjunturais, que o ditador em maio de 1935 teme a "alteração de ordem pública"153. Mas a teoria

${ }^{150}$ José Freire Antunes, «O estadista e o delfim: um destino, dois países» in Salazar Caetano. Cartas secretas (1932-1968), Lisboa, Círculo de Leitores, 1993, 23.

${ }^{151}$ Cf. O. Salazar, Discursos e notas políticas, II, 1935-1937, Coimbra, Coimbra Editora, ${ }^{2^{a}}$ 1945, 32-33.

${ }^{152}$ Vital Moreira, «O sistema jurídico-constitucional do "Estado Novo"» in João Medina (dir.) História de Portugal, vol. XII, $O$ «Estado Novo», Lisboa, Ediclube, 1993, 175 e 180-81.

${ }^{153}$ Escreve Franco Nogueira (o. c., II, 325-26, sub. ns.) "segundo informações da polícia e da censura, existe uma ameaça de alteração de ordem pública. Continuam activos alguns da antiga Liga de Paris e do Grupo de Buda (.). No país, Domingos Pereira e Cunha Leal estão mais ásperos e audaciosos nos seus ataques ao governo e ao sistema. Em Conselho de Ministros a 6 de maio, em Belém, sob presidência de Carmona, Salazar descreve a situação; e o Conselho além de encarar legislação que permita aposentar os funcionários públicos hostis, resolve proibir a Domingos Pereira, Cunha Leal e Prestes Salgueiro, residência em território nacional por dois anos. Três dias mais tarde, a 9, o Conselho aprova o decreto sobre o funcionalismo; e nessa noite Salazar convoca o director da polícia que lhe comunica haver efectuado algumas prisões". A 5 de maio Salazar reunira com Cerejeira e o cónego Carneiro de Mesquita "como nos tempos dos Grilos" $(i b ., 325)$. 
securitária e conspirativa aplicada a Lima é absurda: confronte-se, antes, com medidas de depuração da administração e o reforço confessional no interior do Estado, mormente ao delimitar o ensino pela doutrina e moral do catolicismo hierárquico ${ }^{154}$ veiculada pelo citado decreto n. ${ }^{\circ}$ 1.910. A noção restritiva de bem público, firmada nos comtianos mortos que governam os vivos, sacrificava a liberdade (não interferência) dos antigos $^{155}$.

Quer dizer: «salvação» da República implicava, na prática, a sua destruição. Em "defesa das instituições", uma nota oficiosa de 11 de maio explicita nos jornais o teor do decreto-lei n. ${ }^{\circ} 25.317$, aprovado em conselho de ministros a 10 e publicado dias depois: é o célebre «decreto do 13 de maio» ${ }^{156}$. O documento é a justificação jurídica e política do que se afigura indefensável, sob o ponto de vista ético e social: ditando que os funcionários "ponham a sua actividade ao serviço do Estado e cooperem numa dedicação permanente" e exigindo que "não perturbem a vida da Nação, quer no exercício das suas funções, quer fora delas, constituindo núcleos de resistência contra o próprio Estado". Com base no art. $22^{\circ}$ da Constituição, impedia-se aos agentes do Estado a filiação partidária ou em qualquer "organização de interesses particulares" salvo no partido único, desde 1930 a União Nacional - são expulsos os que mantinham "renitente hostilidade" ao nacional-situacionismo.

Dispositivo «legal» avalista da repressão totalizante e administrativização política, em nome da alegada apolitização da administração, o funcionalismo era mera peça executória e corporativa longa manus da nova ordem ditatorial. O autoritarismo é enunciado como princípio totalitário: a definitiva liquidação do Estado liberal passa pelo controlo das chefias e, no caso do fascismo italiano a partir de 1925-27, pela neutralização de funcionários ou intelectuais hostis, exigindo do funcionalismo não só a adesão mas a mobilização para a causa,

${ }^{154} C f$. António Barreto, «Salazar», DHP, o. c., IX, 339.

${ }^{155} C f$., sobre Skinner e Pettit, Roberto Gargarella, «La comunidad igualitaria y sus enemigos. Liberalismo, republicanismo e igualitarismo», ANDrÉs HernáNEZ (ed.) Republicanismo contemporáneo. Igualdad, democracia y ciudadanía, Bogotá, Universidad de los Andes, 2002, 82-84.

${ }^{156}$ Cf. Diário do Governo, I série, n. ${ }^{\circ} 111,16-\mathrm{V}-1935$, e II série, n. ${ }^{\circ} 173$, de 27-VII-1935. 
a fascização burocrática e administrativa ${ }^{157}$. Na nazificação alemã e correlata liquidação da República de Weimar, a lei de 1-X-1933 perpetra-se em nome da "segurança e unidade do Partido e do Estado": o primeiro passo é o estrangular qualquer actividade do «espírito» ${ }^{158}$ no corpo do funcionalismo; intelectuais, burocratas, expurgam-se ${ }^{159} \mathrm{em}$ nome do racismo psíquico e social contra todas as diferenças da «alma» do Volk, autêntico führerprinzip ${ }^{160}$.

Também em Portugal o abismo totalitário juridicamente se esboça em nome da segurança do Estado e segue pela impugnação e aniquilação do direito subjectivo, literalmente dos direitos das pessoas, a começar nos agentes do Estado. São arbitrariamente aposentados, reformados ou demitidos os "funcionários ou empregados, civis ou militares, que tenham revelado ou revelem espírito de oposição" aos princípios da Constituição corporativa ou que "não dêem garantia de cooperar na realização dos fins superiores do Estado" (art. $1^{\circ}$ ), não podendo ser reconduzidos ou admitidos em quaisquer cargos públicos $\left(2^{\circ}\right)$, nem admitidos em escolas que somente habilitem para o exercício de funções públicas $\left(3^{\circ}\right)$, decisão da qual não haveria recurso senão para o próprio conselho de ministros que a decretava $\left(4^{\circ}\right)$ ficando, além do mais, suspensa por dois anos a regra de inamovibilidade do funcionalismo em geral $\left(6^{\circ}\right)^{161}$. A depuração culminaria, em setembro de 1936, com a promulgação do decreto-lei n. ${ }^{\circ} 27.003$, que impunha a

${ }^{157}$ Cf. Renzo De Felice, Mussolini il fascista. II. L'organizzazione dello Stato Fascista. 1925-1929, Torino, Giulio Einaudi, [reimp., 1994], 342-49.

${ }^{158}$ Racismo psíquico é o termo aplicado por G. Merlio, «A crítica da democracia liberal em Oswald Spengler», Z. Sternhell (ed.), O Eterno Retorno (.), Lisboa, Bizâncio, 1999, 136.

${ }^{159}$ Escrevia em 1933 CARL SCHMITT, teórico nazi, sobre o princípio totalitário: "É total do ponto de vista da sua qualidade e da sua energia, daquilo a que o Estado fascista chama o stato totalitario, o que quer dizer que os novos meios pertencem exclusivamente e têm por finalidade aumentar o seu poder. Semelhante Estado não permite que se erga, no seu seio, qualquer força que possa ser-lhe hostil, limitálo ou fragmentá-lo", apud JERRY Z. MulLER, «A crítica radical conservadora da democracia liberal na Alemanha de Weimar», in Sternhell, o. c., 164. Não se esqueça porém que Salazar vincara a experiência portuguesa da «Revolução», (Discursos, o. c., I, 374).

${ }^{160} C f$. Jỗo Bernardo, Os labirintos do fascismo (.)., Porto, Afrontamento, 2003, 264-65.

${ }^{161} C f$. «O Funcionalismo e o Estado» in Diário de Coimbra, n. ${ }^{\circ} 1692$, de 11-V$-1935,4$, cl.s 2 e 3 . 
subscrição de declaração anticomunista e antimaçónica aos candidatos a qualquer cargo público, reformulando o já estipulado pelo decreto de 21 de maio de $1935^{162}$. Fecha-se a arquitectura corporativa das interdições ao converter o funcionalismo na própria extensão orgânica e vigilante do Estado Novo ${ }^{163}$.

O ditador compulsivamente demite 33 funcionários públicos, sem processo sumário esboçado, ao contrário do que ocorrera com o próprio na sindicância de 1919. Hipertrofiando o dever (de obediência), o ditador destruía o sentido autonómico da República, regime formalmente mantido para melhor nele poder atacar os princípios instituintes, desvirtuando a virtude cívica, desenraizando na República o germe da mínima utopia della libertà politica (e degradando a participação num holismo desindividuador ${ }^{164}$, sem a qual se degrada o republicanismo. O sarcástico "louvável desejo de progresso" que Salazar anunciara então, na República liberal, estava a chegar agora ${ }^{165}$.

A doutrina do dec. 25.317 veiculou-se em órgãos de informação, alguns da área republicana, próximos do regime: em longo artigo de opinião, na $1^{\mathrm{a}}$ página do Diário de Coimbra, sete dias após a nota oficiosa, afirma-se que "ninguém pode dizer que a Revolução não usou de uma longa tolerância para com os seus declarados inimigos que ficaram adentro do próprio organismo administrativo do Estado". O articulista "espantava-se" por permanecerem na administração "muitas daquelas figuras que foram co-autores do descalabro nacional" e que continuaram a ter ligações ou actividades "nas organizações

${ }^{162} \mathrm{~V}$. MoreIra, «O sistema jurídico-constitucional do "Estado Novo"», o. c., 181 .

${ }^{163}$ No citado discurso da Câmara de Lisboa (27-IV-1935) Salazar anunciara doutro modo a expulsão: "os funcionários públicos estão ao serviço da colectividade e não de qualquer partido ou organização de interesses particulares (.). O problema da segurança confunde-se, pois, com o da defesa do Estado no provimento dos cargos públicos e no exercício das respectivas funções" - Discursos, II, o. c., 36.

${ }^{164} C f$. Maurizio Viroli, Libertà politica e virtù civile (...),Torino. F. Giovanni Agnelli, 2004, XII, a contrario.

${ }^{165} \mathrm{Na}$ sindicância de 1919 afirmara: "Sejam quais forem as nossas opiniões pessoais sobre uma ou outra questão, convém sempre ter o nosso espírito aberto aos novos factos e às novas ideias, num louvável desejo de progresso, de rectificação contínua dos nossos conhecimentos"- SALAZAR, A minha resposta, o. c., 23. 
conspiratórias urdidas dentro e fora do país", opondo "muita resistência passiva ao espírito da Revolução" e favorecendo a "obra de destruição que se promovia nas alfurjas secretas". A teoria da conspiração legitima a purga. Contra o argumento - inexacto de resto - que prevalecera na República a prática de tolerância na administração e que o "Estado consentia no seu seio muitos dos seus inimigos", arguía-se com o carácter "orgânico" e "coeso" do "estado revolucionário" e a nova "personalidade jurídica" que este adquirira a partir da "revolução nacionalista" e da Constituição, que coagia os agentes a pactuarem com o "grande objecto de uma reforma transcendental" do "génio de Salazar" a qual, leiam-se os termos, revivificava o "sentido unitário do prolongamento intérmino da Nação". Em nome do unicismo e esmagando a liberdade de consciência pública, a dos indivíduos, não era justificável qualquer argumento contra a expulsão baseado numa "sensibilidade doentia que criasse um ambiente de piedade" e se condoesse dos destinos dos que "se empenharam em corromper e perturbar a ordem social" 166 . Exórdio da impiedade e uso da hipocrisia moral em política e da moral confessional para exportação. Desligado do serviço, eufemismo oficial para a bárbara expulsão, Lima saberia que também ele se incluía no rol dos que cometeram as "mais graves ofensas contra a Pátria". Na mesma página do jornal, ao lado, elogia-se a invasão fascista da Etiópia.

"Vemos erguerem-se por toda a parte, congestionada e feroz, os cabelos revoltos e de olhos injectados, a face em fúria de Belona...", anota Rodrigues Miguéis ${ }^{167}$. Outro jovem escritor replica: "o que eu vejo hoje - e a fúria hitleriana ainda não alcançou o seu êxito completo - é um ódio feroz contra os homens". Urdia-se "a atroz e sanguinária" caçada aos judeus ${ }^{168}$. E a espíritos livres, por cá.

166 «Funcionários» (R. DE L.), Diário de Coimbra, n. ${ }^{\circ}$ 1699, de 18-V-1935, 1, cl.s 1 e 2. Sub.ns.

${ }^{167}$ José Rodrigues Miguérs, «Sobre a eficácia das ideias», O Diabo, n. ${ }^{\circ}$ 4, 21-VII-1934, 1.

${ }^{168}$ ManUel FiliPe, «Einstein, cidadão do mundo (...)», O Diabo, n. ${ }^{\circ}$ 53, 30-VI$-1935,3$. 


\section{A expulsão de um universitário e a vaga expurgatória}

A torrente dos acontecimentos há muito transbordara. A demissão do director da Biblioteca da Universidade e posterior encerramento inesperado ${ }^{169}$ da Imprensa da Universidade ${ }^{170}$ em 30 de junho de 1934 com a exoneração coerciva do director que vinha movendo notável e fecundo exercício formativo, editorial e cívico desde 30 de julho de $1921^{171}$, impediriam a acção heterodoxa de Joaquim de Carvalho (expressão de Sílvio Lima) em bases programáticas ${ }^{172}$. "Estes dois traumatismos", aclara postumamente o discípulo, "geraram nele certo

${ }^{169}$ Pelo processo de actuação. Contudo, Joaquim de Carvalho atribuía-lhe um carácter maquiavélico, como escrevia a João de Barros (1-VIII-1934), "até me dão a honra de ser coveiro dos melhores anos da minha vida. A coisa foi longamente pensada e decantada, e no fim apenas se justifica com a actual Constituição, que não permite ao Estado a concorrência com a indústria particular" - JOAQUIM DE CARVAlHo, $O C$, VIII, 134-35.

${ }^{170}$ No art. $38^{\circ}$ da lei de meios desta data, conjugado com o decreto-lei 24.124, extinguiam-se os serviços da Imprensa da Universidade de Coimbra e a 29 de agosto o decreto-lei 24.440 determinava o fecho das instalações a 31 desse mês. Os trabalhos em tipografia foram mandados para Lisboa, sendo depositária a Imprensa Nacional. Aí se topava com o "estado verdadeiramente caótico em que tudo se encontrava amontoado, empastelado - originais, provas, folhas impressas das mais diversas obras (...) Ao que parece decorridos anos toda aquela papelada foi vendida a peso. Os alfarrabistas, farejando bens interessantes, pegaram-lhe" - António Ferrão, «O Prof. Joaquim de Carvalho e a sua época», Miscelânea de Estudos a Joaquim de Carvalho, o. c., 232.

${ }^{171}$ Cronologia e alguns informes, em http://www.imp.uc.pt/historia/índex. php?lang =pt, 22-VI-2007.

172 Carvalho é acusado de ceder à Reacção na extinta Imprensa da Universidade, no artigo violento de Albano NogueIRA («Um pensador em segunda mão»; $O$ Diabo, n. ${ }^{\circ}$ 23, 2-XII-1934, 8) que impugna a edição de Manuel Anselmo (Soluções críticas) e sobretudo João Ameal (No limiar da Idade Nova), que "além da copiosa bebedeira que sempre apanha (.) é supinamente ridículo" ao copiar "falsidades" de Maritain, Bardieff, Henri de Mann. J. De Carvalho (O Diabo, n. $\left.{ }^{\circ} 24,9-X I I-1934,6\right)$, aclara que há dois anos incitara Ameal, sem prefixar o tema, de modo "a dar a uns jovens o sentimento de responsabilidade intelectual, a outros, ânimo para se revelarem, e ao público o panorama da nossa juventude actual", pois a colecção não era "monopólio de uma tribu, nem monólogo de um élan literário": "o meu impenitente e já agora inconvertível liberalismo não me consentia outro procedimento" e quanto mais dispersa e díspar colaboração "tanto melhor para a República das Letras e para a exemplaridade da sua cidadania". Títulos que "celebraram, portanto, os funerais da Imprensa da Universidade": Saavedra Machado, O Desenho e as mulheres no labor artístico de Rafael Bordalo; Carolina 
medo, inteiramente humano, certa insegurança de vida", debilidade legível à luz da biografia do filósofo pobretana (como o próprio Carvalho dizia) que não poderia continuar, em plena latitude e liberdade ${ }^{173}$, a acção formativa e reformadora que se propusera à frente da Imprensa universitária ${ }^{174}$. Foco decisivo de livre difusão, plural e contraditória, cujo raio de visibilidade intelectual era o mais vasto na cultura portuguesa, desaparecia por simples decisão administrativa, entre o clamor daqueles que, nos campos mais diversos (Fidelino de Figueiredo, Alfredo Pimenta, Hipólito Raposo, Vieira de Almeida, António Sérgio) se indignaram.

A própria tentativa de Joaquim de Carvalho, com Mário de Azevedo Gomes e Hernâni Cidade, de reerguer um projecto mediático, mais vasto e doutro teor, logo em 1933-34, que resistisse ao avanço da barbárie juridicista, o Diário Liberal, saiu lograda: o jornal seria extinto e os directores alvos de processo judicial, em 1936, no qual pairou o espectro da condenação ao degredo para o Tarrafal, o que não tendo consequências imediatas, provocaria sequelas ${ }^{175}$. Não teriam sido portanto dois mas três os eventos traumáticos que nessa época inibiram em J. de Carvalho mais desafrontada acção política, embora o exercício intelectual e a prática do magistério universitário não indiciassem debilidades. Sabe-se como, a partir doúltimolustre da década de 1930, comaliquidação da livre opinião pública e com o reforço dos instrumentos inibidores ou dissuasivos, com a montagem e o sucessivo aperfeiçoamento da máquina monopolizadora e repressiva do Estado Novo, o processo da

Michaëllis, Estudos sobre o romanceiro peninsular; Nuno Simões, O Brasil e a emigração portuguesa e Quirino da Fonseca, A Caravela portuguesa.

${ }^{173}$ Sílvio Lima, «Carta a Sant'Anna Dionísio» de 13-V-1966, OC, II, 1680. BMPFT-FF, Espólio Joaquim de Carvalho, Cx. Arquivo Pessoal, PES - 31.1., pasta Arquivo de Família.

${ }^{174} C f$. Sílvio Lima «Carta a Sant’Anna Dionísio» de 13-V-1966, OC, II, 1680.

175 Joaquim Montezuma, em mns. de 17-VII-2002, nota que o Diário Liberal foi reprimido à nascença levando em 1936 "os três catedráticos a julgamento no tribunal da Boa Hora por «crime» de ofensas à corrupção salazarista entronizada por Guilherme Pereira da Rosa, director de O Século". Ilibados, o espectro do desterro não deixou de pesar sobre as suas cabeças: "O juiz do processo a julgamento absolveu os 3 co-réus mas logo a seguir pediu licença e não voltou ao cargo (sabia que ia ser perseguido sempre). Estavam ameaçados com a pena de degredo para o Tarrafal, na ilha do Sal." - BMPFT, Espólio Joaquim de Carvalho, Cx. Arquivo Pessoal, PES, 31.1. 
produção e circulação informativa, científica e cultural foi bipolarizado de modo crescente entre o nacional-situacionismo e a resistência comunista, que em breve adquiria a expressão do combate cultural neo-realista. Tem sido evidenciado o modo como os dois blocos hegemonizariam discursos e representações simbólicas, cancelando ou dissolvendo o impacto do pensamento livre que transpusesse as fronteiras mutuamente vigiadas: "o velho liberalismo - o do seu Pai e o meu - mostra-se mais uma vez impotente", escreveria muitos anos depois Sílvio Lima a Joaquim Montezuma numa carta interceptada pela PIDE, em plena crise académica de 1969. Esse representava "o grande drama das consciências democráticas, entaladas entre estes dois abismos". ${ }^{176}$

Mestre e discípulo, no espaço de meses e em episódios indesligáveis pagavam com o tributo da liberdade ao ditador. O decreto 25.317 pode ser visto, em antífrase, como a profilaxia "do tráfego e da circulação de ideias que infectassem o nosso organismo social vitaminando-o com doses maciças de mezinhas de inspiração nacionalista e cristã", num quadro em que na escola se centrara a luta contra a «traição» desnacionalizadora e o «perigo» de doutrinas irreligiosas ${ }^{177}$. Salazar ${ }^{178}$ governando "como um bonzo oriental com decretos-leis arbitrários", dirá Sílvio Lima ${ }^{179}$, abria juridicamente as portas (naquela ideia catedrática do salazarismo, de que jurídica é qualquer forma de lei

${ }^{176}$ Sílvio Lima, carta de 21-VII-1969, apud L. R. Torgal, «Um homem humilde mas livre na sua investigação», Estudos em homenagem a João Francisco Marques, Porto, FLUP, s. d. (2001), 491. Sub. de Sílvio Lima.

${ }^{177}$ Rómulo de Carvalho, Historia do Ensino em Portugal, o. c., 753.

178 À beira da morte, Joaquim de Carvalho redige um glossário avulso de memórias, editado por Joaquim Montezuma. Leia-se «Joaquim de Carvalho e o salazarismo», Mar Alto, n. ${ }^{\circ}$ 403, 4-V-1974, 1 e 8, «Seminarista»: "Foi o tipo acabado de ressentido e de frustrado. Quis ser Padre e a República não lhe deu convicções (.) o facto de abandonar o seminário de Viseu e de se preparar para uma profissão liberal põe às claras o seu sentido oportunista...Abandonando o seminário nem por isso deixou de ser um seminarista na formação e no ideal de vida: celibatário governou como um bispo governa a sua diocese, e deu categoria aos ex-seminaristas, pelo que com graça se dizia que Salazar era o chefe do «nacional-seminarismo». A frustração dos seus ideais no Seminário gerou-lhe o rancor pela República e a saudade pelo mundo que ela veio - ou quis - enterrar".

${ }^{179}$ Sílvio Lima, «Carta abertaàs universidades portuguesas», Diáriode Coimbra, n. ${ }^{\circ} 15.077,8-\mathrm{V}-1974,1, \mathrm{cl} .3$. 
no Diário do Governo) para que um conjunto dos mais prestigiados intelectuais universitários portugueses, e outros agentes do estado, integrados numa lista negra de funcionários públicos civis e militares, fossem expulsos compulsivamente das suas funções. Integravam o grupo heterogéneo de cidadãos, Nuno Simões, director-geral do Supremo Tribunal Administrativo, Adelino da Palma $\operatorname{Carlos}^{180}$, jovem jurista então assistente do Instituto de Criminologia de Lisboa, o general Norton de Matos ${ }^{181}$, professor do Técnico, Jaime Carvalhão Duarte ${ }^{182}$, Bernardo José Costa Amaral e Manuel da Silva professores do Ensino

${ }^{180}$ Natural de Faro (1905-1992), foi Palma Carlos advogado destacado na defesa dos direitos humanos e dos opositores políticos à ditadura, desde logo os revolucionários de Fevereiro de 1927 (general Sousa Dias e coronel Freiria) e em 1947. Aluno excepcional, fundou na FDL a Liga da Mocidade Republicana (1923). Doutorado (1934) em Lisboa, a expulsão de 1935 impediu-o de seguir carreira académica, na qual posteriormente ingressaria vindo a dirigir a Faculdade de Direito (1965-1970). Com intensa vida e obra ligada ao Foro ligado a inúmeras organizações jurídicas internacionais e ao grande comércio e indústria, comissário da candidatura Delgado, seria primeiro-ministro no I governo provisório saído da Revolução de 1974, cargo do qual se demitiria em julho.

${ }^{181}$ José Mendes Norton de Matos (Ponte de Lima, 1867-1955), bacharel em Coimbra (1888) membro do partido Democrático, grão-mestre do GOLU (1930-35), antigo ministro das Colónias e da Guerra que preparou o CEP, abatido ao efectivo do Exército em 1917 por Sidónio Pais; em 1928, a ditadura militar fixa-lhe residência nos Açores, regressa em 1930. Será opositor a Carmona nas eleições presidenciais de 1949. Para uma nota biográfica sucinta, ANICETO Afonso, «Norton de Matos», in Jõ̃o Medina (dir.), História de Portugal, vol X, A República, I, Lisboa, Ediclube, 1993, 256-262; e Oliveira MArques, A Maçonaria e o Estado Novo, o. c., 60-61. Cf. as suas Memórias e trabalhos da minha vida, vol. I, Lisboa, Editora Marítimo Colonial, 1944.

${ }^{182}$ Jaime Carvalhão Duarte (1897-1972), docente de Educação Física na Tutoria Central de Lisboa, donde é expulso em 1935, secretário geral da União dos Professores Primários, propagandista e pedagogo republicano, "impelido pelo entusiasmo e pelo carinho que sempre me mereceram os assuntos da instrução popular", "debate e estudo dos problemas do ensino e valorização da Escola". $\mathrm{Na}$ evocação do mestre Joaquim de Carvalho, referia: "e se impedido fui do exercício do magistério, como jornalista continuei, porém, a viver o meu sonho", convicto que "a Imprensa constitui, além de um poderoso meio de divulgação e de cultura", "a obra de educação que lhe incumbe" no sentido da libertação popular "dos ignominiosos grilhões da ignorância" e da mancha negra do analfabetismo - c.f.CARvalhão Duarte, Miscelânea de Estudos a Joaquim de Carvalho, Figueira da Foz, B-MJC, n 4, 1960, 431-432. Activista da defesa dos presos políticos, seria redactor e director de A República, e autor da obra apreendida $O$ Ditador $d a$ violência (1933) “pela sua índole de ataque político", regista a GEPeB, VI, 64. 
Primário, a que se juntam outras personalidades ${ }^{183}$, como Álvaro Viana de Lemos ${ }^{184}$ ou o coronel Norberto Ferreira Guimarães ${ }^{185}$. Seria ainda o caso da exoneração compulsiva (25 de Julho de 1935) do secretário da Universidade de Coimbra, José de Oliveira Neves, acusado por ligação orgânica ao republicanismo maçónico e recentes intervenções públicas contra a ascensão nazifascista na Europa ${ }^{186}$. Acompanhavam-nos os

${ }^{183}$ Também Hernâni Cidade (1887-1975) se encontrava na lista negra dos professores a expulsar, mas foi retirado por pressão pessoal de Cordeiro Ramos, seu amigo, junto de Salazar, como relatava sua filha Helena Cidade Moura, in (2-II-2007) http://www.instituto-camoes.pt/cvc/figuras/ hcidade.html.

${ }^{184} \mathrm{O}$ caso de Álvaro Viana de Lemos (1881-1972), particularmente grave, não decorre do decreto depurador. Pedagogo republicano e adepto da escola nova internacionalmente reconhecido, a opinião reaccionária (Correio de Coimbra e Diário de Coimbra) ao longo de anos difamou o seu magistério e postura intelectual, sendo confrontado com falsas denúncias dalguns antigos alunos, mestres-escola, que em processo de intenção, ao que parece ministerialmente orquestrado, levariam Lemos a pedir a aposentação da Escola do Magistério Primário de Coimbra (outubro de 1934). Em 1935, descrevia a situação a Adolphe Ferrière, com quem mantinha estreitos contactos e planos (e com Freinet, Claparède): "os inovadores educacionais estão mais ou menos marginalizados, uns exonerados oficialmente, outros objecto de todo o tipo de perseguições" - AnTónio Nóvon et alii, Sobre a Educação Nova. Cartas de Adolfo Lima a Álvaro Viana de Lemos (1923-1941), Lisboa, EDUCA, 1995, 79-81.

${ }^{185}$ Dos expulsos referidos in João MadeIRA (ed.) Vítimas de Salazar - Estado Novo e violência política, Lisboa, A Esfera dos Livros, 2007, 186, omite-se Sílvio Lima. Não se entendem critérios de selecção, a haver.

${ }^{186}$ As duas hipóteses complementam-se: Nídia GreGóRIO, «Subversão e repressão na Universidade nos inícios do Estado Novo. Dois casos exemplares», Ideologia, cultura e mentalidades no Estado Novo.(.), L.ReIs Torgal (ed.), Coimbra, FLUC, 1992, 34-35. O exílio parisiense de J. Oliveira Neves é abordado por TorgA, A Criação do Mundo ( «O Quarto Dia», Coimbra, Ed. do Autor, Gráfica de Coimbra, 1991), retrato dum orador compulsivo e "máquina de pensar", reconhecido no meio universitário. No Livro dos Quartanistas de Direito.1925-1926 (Coimbra, s. ed., 1926, 28), leia-se quadra não assinada: "Intangível, supremo, genial // Outro Voltaire vais ser em Portugal". Torga biografa o "herói triste da existência" (incarnado no Navarro): "Posto na fronteira sem passaporte, vagueava pelo mundo, de terra em terra, com autorizações provisórias de residência, a mover-se numa preguiça sonolenta (.) recusava-se a qualquer conivência afectuosa, como se temesse perder no terreno da sentimentalidade a lucidez implacável” (o. c., 291). Cf. Carlos Santarém Andrade, Os dias de Coimbra na criação de Miguel Torga, Coimbra, CMC-CCRC., 2003, 91-92.

Adolfo Rocha, ao publicar $O$ quarto dia, seria preso no Aljube e na sede da PVDE e o livro apreendido em dezembro de 1939, «instruindo» o processo 
demitidos dos serviços da administração central ou judicial os bacharéis Germano Martins (director-geral dos serviços centrais do Ministério da Justiça), Adriano António Crispiano da Fonseca (juiz do $8^{\circ}$ Juízo Criminal de Lisboa), Luís Loureiro Melo Borges de Castro (conservador da $4^{\text {a }}$ Conservatória do Registo Civil de Lisboa), Domingos Leite Pereira (chefe do serviço judicial da $5^{\text {a }}$ Vara de Lisboa), Álvaro Manuel dos Santos Silva Machado (chefe de repartição na Direcção-Geral de Comércio e Indústria), António Tavares Pereira (chefe de repartição no Instituto Geográfico e Cadastral) e o eng. . Artur Guilherme Rodrigues Cohen (chefe dos serviços geológicos da Direcção-Geral de Minas); das Forças Armadas foram demitidos, além de Ferreira Guimarães, o general Joaquim Mendes Cabeçadas (1868-1939), majores Eduardo Rodrigues de Areosa Feio e Matias dos Santos, o capitão Mário Ferreira Pimental e o tenente Francisco Ferreira Sarmento Morais Pimentel (familiar do seareiro exilado no Brasil desde 1927, João Sarmento Pimentel, activo na Santa Liberdade); ainda os professores Manuel de Sousa Coutinho Júnior (Liceu Gil Vicente, Lisboa), Eduardo Ferreira

policial o próprio ministro do Interior, Mário Pais de Sousa (Renato Nunes, Miguel Torga e a PIDE. A repressão e os escritores no Estado Novo, Coimbra, Minerva, 2007, 40-72). Imagens icásticas da Espanha franquista e da Itália fascista eram demasiado incómodas para a ditadura e evidentes para o mediano leitor. Mas pensamos acrescer outra mais decisiva motivação para a proibição do livro e prisão do escritor. Narrativas do exílio, a suposição de um lado de lá do Estado Novo, objectivada em portugueses (embora nomes ficcionados, pessoas reais), passando muitos as piores privações e testemunhando a genuína humilhação de uma pátria que os persegue, eram inadmissíveis para a celebração contínua e paranóica da «portugalidade». Ao admiti-lo, o Estado Novo teria de reconhecer que ele próprio caucionava a violência que provocara o exílio; ora a «história sagrada» do exílio (Hannah Arendt), prolongando a ideia medieval das «tréguas de Deus» na qual há um qualquer lugar onde o sagrado se realiza no respeito do outro, era questionada em nome da defesa da cristandade e ocidentalidade. E isso seria o mais absurdo de admitir, para quem tratava os opositores, embora socialmente os diferenciando no tratamento (Irene F. Pimentel, A história da PIDE, Lisboa, Temas \& Debates, 2007, 361), como «malfeitores», «bandos», «criminosos», não como refugiados políticos dissidentes, homens livres. Questão perceptível ao nível do tratamento dos agentes policias, do «tu» dos interrogatórios ao «o» precedendo o patronímico nos relatórios de informação, constituindo indícios claros dessa linguagem que se manuseia como acto de extermínio da individualidade ou dignidade de outrem. Sobre o conceito de exilado intelectual / refugiado político $c f$. JACQUES DERRIDA, Cosmopolitas de todos os países, mais um esforço!, Coimbra, Minerva, 2001, 21-24. 
dos Santos Silva (Alexandre Herculano, Porto), Alberto Álvaro Dias Pereira (Júlio Henriques e Escola Brotero, Coimbra), doutor Álvaro Isidro de Faria Lapa (Faculdade de Medicina de Lisboa), Fernando Alberto Persyart Pinto Ferreira (director do Instituto Aurélio da Costa Ferreira), Mem Tinoco Verdial (Instituto Industrial do Porto), José Vicente Barata (Escola Industrial da Covilhã), Heitor Eugénio de Magalhães Passos (inspector-chefe, director da zona de Lisboa) e o secretário da FDL, Rafael Augusto de Sousa Ribeiro ${ }^{187}$.

Simultânea expressão da atitude «corporativa» executada através do aparelho de estado e clara administrativização da política, era um saneamento político, no sentido ordinário do termo. É hoje claramente perceptível o processo pelo qual o salazarismo, isto é, o autodenominado "Governo quasi exclusivo de professorado superior", procurava a eliminação de profissionais ideologicamente adversos ou que conferissem visibilidade à outridade ético-política, agindo a governação em termos da putativa «defesa» da "sagrada oficina das almas" e da "fábrica espiritual portuguesa"188.

No apregoado «professorado superior» sobressaem as figuras de Salazar e Eusébio Tamagnini, ministro da Educação, da Faculdade de Ciências de Universidade de Coimbra, recentemente convertido ao salazarismo após passagem pelo nacional-sindicalismo de Rolão Preto. O objectivo estratégico era quebrar a espinha dorsal do pensamento livre e da intervenção desassombrada, intimidando, cortando laços funcionais, desrespeitando a mais elementar honorabilidade universitária. Encontram-se objectivados por este megaprocesso de intenção orquestrado pelo fascismo clerical $^{189}$ (na expressão de Viana de Lemos), com Sílvio Lima, personalidades de inquestionável qualidade intelectual e de nomeada extramuros, como os professores Aurélio Quintanilha, da Faculdade de Ciências de Coimbra, autoridade científica internacional no domínio da fitogenética e botânica ${ }^{190}$,

${ }^{187}$ A imprensa republicana publicita a lista de expulsos: A Voz da Justiça, XXXIV, n. ${ }^{\circ}$ 3.342, 18-V-1935, 1.

${ }^{188}$ Cf. Oliveira Salazar, Discursos (I), 1928-1934, o. c., 302.

189 Da cit. carta a Adolphe Ferrière, ANTÓNIo NóvoA et alii, Sobre a Educação Nova. (), o. c., 79 .

${ }^{190}$ O angrense Aurélio Pereira da Silva Quintanilha (1892-1987), aluno da Faculdade de Filosofia da UC (1909), em 1910 concluí preparatórios da Escola do Exército, sem ingresso, matricula-se em Medicina (Lisboa, 1912) e dedica- 
o filólogo e historiador da literatura, da Faculdade de Letras de Lisboa,

se, após 1915, à prática laboratorial científica, interrompendo medicina para se matricular em Ciências Naturais da FCL, onde é assistente de Botânica (1917-19). Licenciado, Wittnich Carrisso, director do Jardim Botânico, incita-o para assistente de Ciências Biológicas da Faculdade de Ciências de Coimbra, onde apresenta a tese de dissertação em 1926 e prossegue até à expulsão - $c f$. GEPeB, XXIV, 101-103; e Act., IX, 590.

A invulgar actividade pedagógica e a memória da Falange demagógica, em professores tradicionalistas de Coimbra, concitaram anticorpos que agravariam a periclitante posição do docente de inspiração libertária e livre-pensador de raiz acrática. Já em 1924 Quintanilha criticara asperamente, na Seara Nova, o primarismo pedagógico ortodoxo e anacrónico, «catedratismo» propriamente dito, na pessoa de Pacheco de Amorim (do grupo cadcista de Salazar e Cerejeira) por ocasião da «oração de sapiência» por este proferida. E volta à carga, em 1933. A pública denúncia da ausência de liberdade, autonomia, rigor, salutar relacionamento entre mestres e discípulos, falha de responsabilidade cívica, formativa e nulidade científica e investigatória na Universidade, feita a partir das páginas de O Século (n. ${ }^{\circ} 18.331,26-$ III-1933), desencadearia contra si a hostilidade conservadora hegemónica na instituição coimbrã, e no país. A reacção corporativa avança com a moção de censura no Senado, pela mão de Fézas Vital e Mário de Figueiredo e posteriormente na Assembleia Geral, que daria o incidente findo, por pressão dos representantes de Letras, Ciências e Medicina, a despeito da severa censura que alguns lhe movem, incluído o vice-reitor, Cabral de Moncada, mas sem a instrução formal do processo disciplinar. Porém, seria este aspecto que mais directamente motivou a expulsão compulsiva decretada em 1935 - $c f$. NíDia GregóRIO, "'Subversão" e repressão na Universidade nos inícios do Estado Novo», o. c., 64-76. A questão marcou a Direita universitária. M. Figueiredo referir-se-ia em 1935: "não lamenta o afastamento do Dr. Quintanilha, pois tem no pensamento uma Assembleia Geral, única decerto nos anais da Universidade, e a lembrança do que aí se passou não permite que o faça" - AUC, Livro de Actas do Senado, vol. II, (1929-1935), fl. 191. C. DE Moncada (Memórias, Lisboa, Verbo, 1992, 171-72) recorda professores "à bulha" na Assembleia, rodeada nos Gerais por estudantes que davam vivas à República. Quintanilha, contudo, estribara bem a liberdade de cátedra e de crítica no seio da corporação que não questionava já a via única: atacara a ausência de produção científica e cultural dos mestres e de educação artística e desportiva dos jovens e o processo ancilosado e «sem concorrência» de «concursos públicos» na admissão de docentes - acta da Assembleia Geral de 6-V-1933, AUC, Livro de Actas, 1911-1934, onde é chamado a explicitar o sentido da frase: os nossos professores são assim criados sous cloche, por um processo análogo ao que usam os camponeses em França, para a criação das alfaces.

No referido roman a clef, O quarto dia de A Criação do Mundo, Adolfo Rocha retrata nos finais da década de 30 Quintanilha (o "Professor Freire") no exílio parisiense, onde o escritor se desloca, descrevendo a longa viagem pela Espanha, Itália e Suíça. Evoca o antigo professor em síntese de grande realismo, "ao fundo da sala de exames, entre raízes, troncos e amostras de madeira de todas as regiões do 
Manuel Rodrigues Lapa ${ }^{191}$ - incansável no esforço do estudo da história e divulgação da língua e literatura portuguesas -, e Abel Salazar ${ }^{192}$,

mundo, parecia um mago dos bosques. Um mago muito branco e limpo, de barba feita e olhos de doninha". Muito distante do Professor Freire exilado: "Para além da amargura do desterro, havia outra razão de sofrimento mais cruciante ainda: o estar divorciado dos seus alunos, a falta de calor de gerações sucessivas (.) e falou de alegria de ensinar, da aventura de cada lição, do jogo apaixonante e diário de atracções espontâneas e repulsões vencidas, de telepatias naturais ou conquistadas entre a cátedra e as carteiras" e do "amor à ciência, evidentemente, mas por amor a quem vinha procurá-la" - Torga, o. c., 286; 296; SANTARÉm ANDrAde, Os dias de Coimbra (.), 91. Em 1971, Nemésio dedica a Quintanilha o comovido Limite de idade. Apesar dos esforços internáuticos, perdeu-se o rasto do Espólio Aurélio Quintanilha, doado e depositado na Universidade Eduardo Mondlane, Maputo, como da escola se confirmou.

${ }^{191}$ Natural de Anadia, M. Rodrigues Lapa (1897-1989) bibliotecário, professor liceal e, após 1928 na FLL pela mão do antigo professor Leite de Vasconcelos. Em 1929 doutorou-se com As origens da poesia lírica portuguesa, em parte orientada na Sorbonne. Em 1933 o contrato é rescindido na sequência da conferência, «A política do idioma e as Universidades». Da Seara Nova, Castelo Branco Chaves louva a "desassombrada coragem da sua atitude, pela justeza da crítica às imbecilidades do nosso ensino superior e à oligarquia pedagógica de que o país é vítima resignada e infeliz" irmanando-se na "sua digna atitude de protesto". Agostinho da Silva saúda-o pela "coragem e pela sua justa decisão de pensamento" expressando votos de que "nenhum dos nossos amigos terá colaborado nessa infâmia", aditando: "se não estivéssemos em Portugal, ousaria também esperar que apoiassem publicamente o seu protesto, com toda a autoridade que lhe daria a sua posição de mestre". Sanado temporariamente o incidente, Lapa ingressa por concurso como professor auxiliar ainda em 1933, mas a retaliação cedo se faz sentir. Em 1934 é-lhe indeferida a bolsa que usufruía como investigador. Em 1935 é expulso. Dirigiria então o Diabo (1935-37) e na Seara Nova largos anos a colecção Textos literários; coordenando a Clássicos Sá da Costa, em ambas com notável actividade. Preso em 1949 por delito de opinião, intensifica relações culturais com o Brasil, sobretudo a partir de 1954, onde se fixa entre 1957 e 1965, regressando e reanimando velhos contactos com a Galiza. Em 1973 assume a direcção da Seara Nova até fevereiro de 1974. Cf. «Introdução» e «Cronologia sumária», AAVV, Correspondência de Rodrigues Lapa. Selecção (1929-1905), Coimbra, Minerva, 1997, 9-19; 49, 46 [57-58]; José Ferraz Diogo, Manuel Rodrigues Lapa. Fotobiografia, Anadia, CM-CRL, 1997. Luís LindLEy CinTRA, via em Lapa o mais destacado estudioso da estilística da língua mãe - «Rodrigues Lapa» (Seara Nova, VI-1967), Boletim de Filologia, XXVIII (1983), vol. I, Homenagem a MR Lapa, Lisboa, INIC-CLUL, VII-XV.

${ }^{192}$ Abel Salazar (1889-1946) ingressa na Academia Politécnica do Porto depois na Escola Médico-Cirúrgica, doutorado (1915) e catedrático de Medicina (1919), investigador de histologia e embriologia, publicou e dirigiu dezenas de trabalhos e 
figura plurifacetada de médico, investigador e catedrático de histologia na Faculdade de Medicina do Porto - pintor, escultor, filósofo, crítico de arte, publicista -, afastado, como confessa no verbete autobiográfico nesse ano escrito, pelo seu "sistema filosófico" 193 .

Constata-se assim na raiz da depuração de 1935, idêntica substância persecutória: os visados assumiam clara resistência e tinham manifestado publicamente desacordo político ou criticado o crescente cadeado da ditadura e asfixia intelectual, cultural e cívica que o país quotidianamente conhecia. Abel Salazar, Quintanilha e Lapa tinham publicamente assumido a contestação da política universitária do regime. Mas Sílvio Lima, não: questionara o seu radical escatológico e gnóstico, indo o ditador a terreiro na defesa da sua dama. Apesar da teoria da conspiração não se lhe adequar, a intolerância surda permitiu que os excluídos criassem laços de solidariedade entre si. Nesse ano, outros intelectuais não universitários asfixiavam sob a ditadura. José Rodrigues Miguéis exila-se nos EUA, cumprindo dura pena existencial; Agostinho da Silva é demitido do ensino secundário (Liceu José Estêvão, Aveiro) por recusar subscrever a abjuração: "embora não pertencendo a associações secretas e também precisasse de comer", recorda próximo

investigações. Polígrafo (teoria da arte, estética, ensaísmo, divulgação científica), destaca-se a partir de 1924 como pintor e, mais tarde, escultor, com imenso acervo pictórico. Entre 1928 e 1930, reorienta a reflexão filosófica sobre a arte, procurando a sobredeterminação científica da estética, no quadro antimetafísico, materialista e neopositivista (Pius Servien), entende às condições de relação, leis de correlação e leis de evolução, à luz de modelos e linguagens matemáticas a partir do apriorismo formal kantiano ( $c f$.IRENERIBEIRO, «AbelSalazar-reflexões estéticas»,AbELSALAZAR, Notas de filosofia da arte, Obras completas, II, Porto, Campo das Letras, 2000, 9-14). A cisão anticrística, por vezes em tom nietzschiano (v. g., «A potencialidade criadora», o. c., 144-48) marca o pensamento estético e ético do publicista (O Diabo, Sol Nascente, Sul, Seara Nova, Gérmen, O Trabalho, Pensamento) que entre março e agosto de 1934 tenta o exílio em Paris e acusa numa série de textos frontais a asfixia intelectual do país ( A Socialização da ciência, O condicionalismo militante e a ciência, A função social da Universidade,). Reintegrado em 1941 (em Farmácia), membro do MUD em 1945, sofria nova represália, a funcional paralisação do Centro de Estudos Microscópicos que dirigia. Pouco depois morre - GEPeB, XXVI, 678; DHP, IX, 283. C $f$. Norberto CunHa, Génese e evolução do ideário de Abel Salazar, Lisboa, IN-CM, 1997.

${ }^{193}$ Cruz Malpique (1956), apud João Madeira (coord,) Vítimas de Salazar, o. c., 187. 
da morte, "resolvi não assinar o papel"194. Após violências policiais e persecutórias, censura e apreensão de edições e textos, uma detenção vexatória, segue o rumo do exílio sul-americano ${ }^{195}$.

"Ao abrigo do famoso decreto 25.317 de 13 de Maio, em nome da Salus Populi, viu a Nação serem expulsos das suas cátedras, ganhas por méritos próprios e depois de laboriosos trabalhos, todo um grupo de professores - servidores de espírito - projectados para a rua como pestíferos", dirá Sílvio Lima em 1974 (Carta Aberta às Universidades Portuguesas), "como objectos"; "foi a gloriosa «matança de S. Bartolomeu», a «degolação» não dos inocentes mas dos pecadores universitários!". E prosseguia na reflexão distanciada e na revisitação ao histórico locus horribilis: "Sem julgamento prévio do

${ }^{194}$ Agostinho da Silva, A última conversa, o. c., 35.

${ }^{195}$ George Agostinho Baptista da Silva (1906-1994), do Porto rumou a Barca d'Alva, aldeia pobre da Raia, em contacto com a natureza frequenta, juntamente com outros meninos do lugar, a «escola», que não havia, na casa materna. No Porto forma-se em Filologia Clássica, com 20 valores. Doutorado com nota máxima, em 1931, nos escombros da Faculdade, nesse ano concluí a Escola Normal Superior (Coimbra). Docente do ensino liceal, funda o Centro de Estudos Filológicos da Universidade de Lisboa, indo para a Sorbonne e Collège de France, com bolsa da Junta de Educação Nacional, investigar o ensaísmo, a conselho de Joaquim de Carvalho. Uma nota sobre a postura ética e intelectual deste: Agostinho fora discípulo de Leonardo, com quem Carvalho se indispôs em 1919, como se viu. Acolheu o jovem, orientou a investigação e publicou (1933, IU): Miguel de Eyquem, senhor de Montaigne. Dele dirá Agostinho: "apesar de ser um homem da Universidade, não se confundia com o resto da Universidade, estava à parte" (Agostinho da Silva, A última conversa, L. Machado, Lisboa, Notícias ${ }^{3} 1997,59$ ). É Carvalho ainda quem propõe Agostinho, expulso já do ensino, a bolsa na Madrid republicana sob orientação de Américo Castro, onde estuda o misticismo ibérico no Centro de Estudios Historicos. Aí encontra Sérgio, de novo exilado, mestre da sua "segunda Universidade". Na guerra civil Agostinho regressa a Portugal, lecciona no ensino particular (no Colégio Moderno será com Álvaro Cunhal professor de Mário Soares) e funda o Núcleo Pedagógico Antero de Quental. Enciclopedista das colecções Iniciação, Volta ao Mundo e Antologia, por delito de opinião é preso 20 dias na «solitária» do Aljube, em 1943, sendo-lhe apreendida a biblioteca. Exila-se em 1944. Reflexão à margem da literatura portuguesa e Um Fernando Pessoa trilham novas exegeses. Cofundador de universidades e centros de investigação, o idealista e seareiro de acrático optimismo, dá lugar ao profético, extra-ordinário Agostinho (E. Lourenço). Heterodoxa ou paradoxal inteligência, tem sido filão para gurus do «destino nacional». Mas construiu dos mais inspirados textos abertos à exploração dos possíveis da liberdade na literatura pedagógica P. Archer, Caos e razão, Tomar, O Contador de Histórias, 2004, 9-104. 
seu comportamento como funcionários, sem defesa, sem possibilidades de apelo jurídico para as autoridades, abandonados na sua própria Pátria, outro recurso não restou a esses universitários senão acatar a sua coerciva humilhação, devorarem em silêncio e «algemados» as suas vexação e degradação". Sem chamar à colação o seu caso, Lima evocava os professores Quintanilha, "mestre insigne, investigador científico de dilatado renome internacional", e Mário Silva ${ }^{196}$, "discípulo

${ }^{196}$ Sendo clara a similitude (i)legal e material (o articulado de 1-VI-1947 arrola o dec. 25.317), Mário Silva, prestigiado físico, professor, divulgador da teoria da relatividade, não é expulso na purga de 1935 mas em abril de 1948, sequela da depuração massiva (14-VII-1947) contra intelectuais e altos funcionários, réus na abrilada de 47 e alegados "agitadores" que organizavam a Oposição (em torno do MUD) que em 1946 custara a expulsão a Bento de Jesus Caraça (1901-1948), catedrático do ISCEF, preso no Aljube em 1948 e a Mário de Azevedo Gomes (1885-1965), catedrático de Economia da Universidade Técnica de Lisboa e ministro da República.

Se 1935 fecha a abóbada ditatorial, a purga de 1947 é correlata da crise de afirmação externa e interna do Estado Novo, após a perplexidade de 45; em plena «guerra fria», demitem-se altas patentes (vice-almirante José Mendes Cabeçadas Júnior, cap.-tenente Pires de Matos, general Marques Godinho, brigadeiros Vasco de Carvalho, Corregedor Martins e Sousa Maia, coronéis Mendes de Magalhães, Gonzaga Tadeu), capitão Marques Repas, tenente José J. Gaita e do escritor Carlos Selvagem (o coronel Carlos Afonso dos Santos, que rompe com o regime em 1945) e demissão ou aposentação compulsiva, além de Mário Silva da Universidade de Coimbra e de Ruy Luís Gomes (1905-1984) da U. do Porto, preso em 1945, na sequência da formação do MUD na questão das «listas», agora demitido com outros destacados universitários: da Fac. de Medicina de Lisboa, os catedráticos Augusto Pires Celestino da Costa, Francisco Pulido Valente, Fernando da Conceição Fonseca, José Cândido da Silva Oliveira e Adelino José da Costa e o professor extraordinário José Henrique Cascão de Ansiães; da Faculdade de Ciências da mesma Universidade, os catedráticos Carlos Fernando Torres de Assunção, Flávio Ferreira Pinto Resende; do Instituto Superior Técnico, António Augusto Ferreira de Macedo e Arnaldo Peres de Carvalho; do Instituto Superior de Agronomia o catedrático interino Manuel Augusto Zaluar Gomes; do Instituto Superior de Ciências Económicas e Financeiras, João Remy Teixeira Freire, professor extraordinário interino. Foram de imediato rescindidos os contratos Andrée Crabée Rocha (da FLUL), que depois ingressa na FLUC, Luís Dias Amado (da FMUL), Manuel José Nogueira Valadares, Amélio Marques da Silva e Carlos Gibert (todos da FCUL), João Lopes Raimundo (do IST), José Cardo Morgado Júnior (do ISA) e Orlando Morbey Maria Rodrigues (do ISCEF). Na «nota oficiosa» publicada a 15-VII-1947, referia-se ainda que "os indivíduos mandados aposentar ou demitir ou cujos contratos são rescindidos cessarão quaisquer outras funções públicas"cf. Fernando Queiroga, Portugal oprimido, Lisboa, Ed. O Século, 1974, 176-78. 
de Madame Curie, mestre pedagogo de raros méritos, amado de seus discípulos e cidadão modelo de virtudes", sem que as universidades em "unitário bloco granítico espiritual" se insurgissem contra a prepotência do "Átila bárbaro". Ao invés, em "juvenil menoridade moral" anuíram, "curvaram a sua cerviz, autodemitindo-se ipso facto do cumprimento dos seus direitos e deveres" provocando o seu "suicídio moral colectivo"197. De facto, o conselho da Faculdade de Letras, ao qual não comparece Joaquim de Carvalho, regista a 5 de junho de 1935 o ofício da reitoria que veicula a determinação do ditador, sem a contestar com convicção. Só o director, Eugénio de Castro, "lamenta o facto a que este ofício se refere, e por igual forma se manifesta o sentir dos restantes vogais do Conselho", providenciando no sentido de encontrar substituto para as cadeiras que Sílvio Lima regia ${ }^{198}$.

Atenção parece ter merecido o caso ao reitor João Duarte de Oliveira, de imediato ido a Lisboa indagar se o afastamento se prendia com questões universitárias ${ }^{199}$. Face à negativa do ministro E. Tamagnini (vários anos regente na Faculdade de Letras de Coimbra), não o demove a reconsiderar. A expulsão é analisada no Senado universitário, só reunido a 18 de julho, sem qualquer deliberação: Anselmo Ferraz de Carvalho leva à sessão "o afastamento das suas funções" de Aurélio Quintanilha, Sílvio Lima e do secretário-geral Oliveira Neves, declarando "não apreciar o decreto, com base no qual aquele afastamento foi levado a efeito" e enaltece sobretudo a figura de Quintanilha. Mário de Figueiredo, sem discutir a política legislativa, concorda na lógica corporativa com a expulsão do biólogo; mas com Sílvio Lima "lamenta em todos os sentidos o seu afastamento, pois não sabe que alguma vez

Foi revogada a expulsão a Celestino da Costa, Cândido de Oliveira, Flávio Resende e Torre de Assunção, a 9-IX-1947- $c f$. R. DE CARvalho, o. c., 784. Vide a síntese conjuntural, A. H. DE Oliveira Marques, Breve história de Portugal, Lisboa, Presença, 1995, 632-36; DAVID LANDER RABY, «Oposição» e «Oposição Democrática», DHP, VIII, 640-42 e 644-46.

${ }^{197}$ Sílvio LimA, «Carta aberta às Universidade portuguesas», $O C$, II, 1674-75.

${ }^{198}$ Actas da Fac. de Letras, II, o. c., 303. Leia-se o teor das Actas subsequentes.

${ }^{199}$ Relata Duarte Oliveira ao Senado que "foi informado pelo Ex. ${ }^{\text {mo }}$ Ministro de que os factos se não relacionavam com o exercício das funções universitárias" e de que se tratava de uma "medida de ordem geral que não visava especialmente as universidades nem qualquer outro organismo estatal" razão pela qual o reitor se vira impossibilitado de actuar - AUC, Livro de Actas do Senado, mns. s. cota, n. ${ }^{\circ} 4$, (1929-1935), fls. 191v-192. 
tenha deixado de defender o prestígio da Universidade e, ao contrário, sempre se mostrou disposto a ajudar a mantê-lo". Coerente, ministro da Educação, em 1942, reintegra-o. Almeida Ribeiro, Pinto Basto e Paulo Pires lamentam, sustentando o primeiro, um moderado (o último reitor eleito até 1982), que "há muito defende a ideia de que tais medidas não devem aplicar-se"; e se reconhece que "as circunstâncias hoje são outras", não deixa de refutar a expulsão: "assim como antigamente veria com desagrado um facto idêntico, também hoje o vê igualmente com desgosto" 200 .

No frouxo protesto, sintetizava Sílvio Lima em 1974, Minerva "apeada do seu pedestal de deusa soberana", tornara-se "escrava" da politique d'abord ${ }^{201}$ do "S. to António de Santa Comba"202. Demitido ao "desabrigo" do citado decreto (o "massacre não de S. Bartolomeu, mas de Santa Comba"203) Lima inicia a longa travessia do deserto ${ }^{204}$, esses seis anos e oito meses de infinita e indizível agonia moral, descrita ao próprio Cerejeira (1940)205: “à maldade incansável de uns tantos homens, devo eu este facto: ter sido, em plena mocidade, irradiado duma universidade, onde sempre trabalhei primeiro como estudante, mais tarde como professor honesto e sério. Há 5 anos que arrasto, silenciosamente, uma infinita e indizível agonia moral" "Solidão moral", "assassínio moral" são os termos"206: "Triste país, o nosso, e

${ }^{200} C f$. ib., fls.190-192v. A última acta do livro não é assinada pelo secretário-geral interino, J. H. de Sousa Seco, nem pelos directores, auxiliares e assistentes presentes, João Duarte de Oliveira (reitor), Mário de Figueiredo, Fernando Almeida Ribeiro, Anselmo Ferraz de Carvalho, Egas Pinto Basto, Paulo Pires e Alberto Cunha Marques. A Faculdade de Letras não se representou. A lápis indica-se o lugar das assinaturas: "Reitor // Sr. Dr. Cabral Moncada // Mário // Vaz Serra // Almeida Ribeiro // Anselmo // Tamagnini". Não assinada mas exarada no respectivo livro a acta pode não ter sido aprovada, suscitando reservas probatórias.

${ }^{201}$ Sílvio Lima, «Carta aberta às Universidade portuguesas», OC, II, 1675.

${ }^{202}$ Id., [Na festa dos 70 anos], texto lido a 3 de Fevereiro de 1974, Espólio familiar.

${ }^{203}$ Carta de S. Lima a Barahona Fernandes, 16-X-1978, em parte in B. FernanDES, Biblos, LV, o. c., VIII.

${ }^{204}$ José Ferreira DA Silva, «Sílvio Lima. História de um professor universitário», ib., XXXVII-VIII.

${ }^{205}$ Cópia (autografa) da carta ao Cardeal Cerejeira, não datada, 1940, Espólio familiar.

${ }^{206}$ Carta a M. de Figueiredo, 10-I-1950, BGUC, Espólio do Doutor Mário de Figueiredo, Inventário, n. ${ }^{\circ} 31$. 
tremenda idade de ferro" ${ }^{207}$, escreve na idade do Ferro. Derrame inútil de cânticos sobre as pedras de Jerusalém: não é razoável hoje subsistirem dúvidas sobre o móbil exacto da expulsão de Sílvio Lima. Ao imporlhe o ostracismo intelectual e cívico, acto de violência simbólica, o ditador visava a (frustrada) aniquilação mental e a morte semiótica, intimamente penosa.

\section{A constitucionalização póstuma da expulsão}

A expulsão não dirimia uma questão escolar, que não era. Insere-se na política de destruição da escola republicana ${ }^{208}$ e laica e no combate teórico pela hegemonia dos saberes, concertada ofensiva pelo domínio político e científico das universidades (bloqueando expectativas de todos os que ao jugo se opunham ${ }^{209}$ e pelo domínio simbólico do estatuto científico da psique e gestão pedagógico-administrativa da «alma», i. e., pelo controlo político dos mecanismos do saber, em desigual combate ideológico - no qual aos adversários o ius imperium reserva sistema articulado de condicionamentos (penas, exclusões, prisões, privações) -, combate também pelo conhecimento da psique, arbitrado nos círculos mais estreitos do poder no quadro já não da «instrução pública» mas da «educação nacional», plasmada em novo ministério em 1936. A questão, de raiz, é obviamente política e ideológica. O veio múltiplo da atitude intelectual de Sílvio Lima, na defesa arrojada da libertas philosophandi e de cátedra, a pioneira investigação do psiquismo conduzida ao arrepio de referências gnósticas e mágico-místicas, a polémica com Cerejeira e a edição de $O$ Amor Místico, afrontavam repetidamente o alicerce fideísta do nacionalismo, quer a efectiva imposição intelectual do «nacional-seminarismo».

Investido por si próprio, o Estado ataca a secularização que o republicanismo objectivara no ensino: o «exílio de Deus» legitimava a mundividência formativa do indivíduo-cidadão e a religiosidade

${ }^{207}$ Cf. id., cópia autografa, não datada, 1940, $f$. 2, Espólio familiar.

${ }^{208} C f$. J. P. Avelãs Nunes, A História Económica e social na Faculdade de Letras, o. c., 36.

209 JoAQUim BarRadas de CARVAlho, O obscurantismo salazarista, Lisboa, Seara Nova, 1974, 13. 
cívica da qual a Escola seria capital mecanismo sociabilizador ${ }^{210}$. Haveria que extirpar da ordem jurídica o legado laico da República. Apesar da inicial redacção indiferentista do art. ${ }^{\circ} 45^{\circ}$ da Constituição, a pontual revisão de 1935 , de 23 de março (Lei n. ${ }^{\circ} 1.885$ ) introduzia subtil distinção ${ }^{211}$ no Título $\mathrm{X}$, abrindo portas à Concordata de 1940 e à ulterior consagração do Catolicismo como "religião da Nação Portuguesa", princípio plasmado na revisão de 1951 (Lei n. ${ }^{\circ}$ $2.048)^{212}$. O que, se não sagrava ainda a confessionalidade do Estado (mas a da «nação» na qual o Estado se subsumia), em definitivo o afastava da religiosidade cívica e da «política de produção de mitos» (Emílio Gentile) à maneira fascista ${ }^{213}$, recorrendo à iconologia católica num processo que lhe retirava contudo a força da sacralização da política e lhe neutralizava o misticismo estatolátrico (ou nele se fundia), no plano doutrinal e simbólico, pela intersecção da moral e fé tradicionais. Razão suficiente para ser uma ditadura consentida pelos católicos, na asserção que Proença bem viu; e daí o estorvo de a abater,

${ }^{210} C f$. Fernando Catroga «Religião civil e ritualizações cívicas (EEUU e França)», Entre Deuses e Césares, Coimbra, Almedina, 2006, 227.

211 "Das relações do Estado com a Igreja Católica e demais cultos" passou a designar-se "Das relações do Estado com a Igreja Católica e do regime dos cultos" suprimindo o plural acolhimento no corpo constitucional.

${ }^{212}$ A anterior redacção do art. $45^{\circ}$ da Constituição de 1933 postulava a igualdade civil de todos os cultos, "é livre o culto público ou particular de todas as religiões"; A lei n. ${ }^{\circ} 2.048$, de 1951, dá nova redacção ao $\operatorname{art}^{\circ} 45^{\circ}$ : "é livre o culto público ou particular da religião Católica como religião da Nação Portuguesa”. E adita: "A Igreja Católica goza de personalidade jurídica, podendo organizar-se de harmonia com o direito canónico, constituindo por essa forma as associações ou organizações cuja personalidade jurídica é igualmente reconhecida" - Constituição Política da República Portuguesa, Coimbra, C. ${ }^{a}$ Editora, 1951, (ed.) Afonso QuEIRó, 20-21.

${ }^{213}$ Emilio Gentile, Il culto del Littorio, Stanley Payne, Historia del Fascismo, Madrid, Planeta, 1995, 277-81. Mussolini, pontífice da religião fascista e seu objecto idolátrico, aceita o catolicismo como expressão da Romanità, nacionalista «religião de Itália» sobreposta a qualquer sentido ecuménico. Só o universalismo fascista (a oficial Escola de Mística Fascista é criada em 1930) à luz do qual Roma moderna não é mais do que dilação ou retorno à Roma eterna, poderia substituir o universalismo cristão, motivo para organizações católicas, desde logo em 1932, a Acção Católica, apesar do Pacto de Latrão, entrarem na semi-clandestinidade, sendo expulsos do PNF os ultracatólicos. Apogeu do culto da Romanità, o bimilenário de César Augusto comemora-se em 1937-38. 
pois "as ditaduras, quanto mais constitucionais e quanto mais consentidas, pior" 214 .

A esta luz, a expulsão de Sílvio Lima, na especificidade do seu caso, estabelece o paradigma da diferença, desde logo face ao suicídio dos catedráticos que à insurreição optaram pelo silêncio; depois, por evidenciar o modo como Salazar concretizara a política do espírito, esvaziando dos templos do saber os que punham em causa, como hipótese metafísica para a reflexão e praxis pedagógica da cidadania conceito de liberdade de consciência e de crença que formalmente até então a ditadura em República não refutara -, a imposição burocrática e educativa das verdades eternas, numa linha que bem se ajustava à longa duração da prática da intolerância como preceito legal. Assim, em definição constitucional prudente que afastava uma imediata leitura teocrática ${ }^{215}$, aclara-se que o autoritarismo (se) engendrara (n)um sistema "ultra-catholique dans la substance des choses mais pas officiellement". Há dois indícios fortíssimos para aduzir aqui esta alegação.

Primo. Salazar viu-se obrigado, dez dias após promulgar o decreto 25.317, a alterar o art. $^{\circ} 43^{\circ}$ (Título IX) da Constituição, em sede de revisão constitucional para a qual excepcionalmente a Assembleia Nacional tinha poderes. A nova redacção inserida pela referida Lei n. ${ }^{\circ}$ 1.910, mantendo o articulado anterior - obrigatoriedade do ensino primário $\left(\S 1^{\circ}\right)$, fomento de artes e ciências "que respeitem a Constituição, a hierarquia e a acção coordenadora do Estado", a não pendência de autorização para o ensino religioso em escolas particulares $\left(\S^{\circ}\right)-$ adiantava contudo, no $\S 3^{\circ}$, novo princípio doutrinal. O Estado não só se desvinculava da anterior vigilância da neutralidade religiosa no ensino ministrado nas suas Escolas, em pacto de não-agressão ("o ensino ministrado pelo Estadoé independente de qualquer culto religioso, não o devendo porém hostilizar"), como se obrigava a assegurar não já o aperfeiçoamento vago das "virtudes morais e cívicas", mas as concretas "virtudes morais e cívicas, orientadas pelos princípios de doutrina e moral cristãs, tradicionais do País" ${ }^{16}$. Arcando com a «educação,

${ }^{214}$ Raul Proença (Seara Nova, n. ${ }^{\circ}$ 265, 1-X-1931), Polémicas, Lisboa, D. Quixote, 1990, 923-31.

${ }^{215} \mathrm{~S}$. PAINE, «Autoritarisme portugais et autoritarismes europeens», Rev. de História das Ideias, 16, 1994, 16.

${ }^{216}$ Cf. Constituição Política de 1933, o. c., 19. Sub. ns. 
ensino e cultura nacional», o Estado Novo jurava-se crente numa fé e militante de uma causa: o Catolicismo ou, melhor, a sua leitura autocrática e perene.

Sem acesso a outras provas documentais, será ilógico supor que a nova redacção do artigo $43 .^{\circ}$ visava expressamente Sílvio Lima? Mas o poder - Salazar - percebeu que havia uma brecha no tijolo constitucional que urgia cimentar. Com a típica obsessão de juridificar o injustificável e de justificar o injuridificável, o ditador apaziguou a boa consciência catedrática com uma pazada na lei, legitimação retroactiva da morte semiótica decretada semanas antes. Sem constitucionalizar o confessionalismo, o Estado Novo confessava-se. Fundada na demorada análise e reflexão do caso Sílvio Lima, evidencia-se que Salazar não só dirimiu o conflito religioso em sede da Constituição como projectivamente acautelou possíveis e análogas sedições. E calava a sua (má) consciência jurídica: a lei era escrita.

Um segundo indício esclarece o carácter paradigmático que Salazar conferiu à expulsão de Sílvio Lima. Sabe-se que foi o governo português ${ }^{217}$ quem conduziu expressas diligências junto do reitor da Universidade Católica de Lovaina, para aí se encontrar um doutorado em psicologia e ciências da educação em vista à substituição do apóstata universitário. O problema Sílvio Lima, i. e., a incapacidade de reconhecer alguém no país que, em 1935, o pudesse revezar com mínima creditação científica, politicamente tornou-se em questão de Estado; e em prioridade governativa o ensino de psicologia em Coimbra $^{218}$. Quem o afirma é o substituto em depoimento peculiar, insuspeito, que pela sua relevância se encontra quase integralmente editado na nossa dissertação. No texto escrito em 1990, Émile Planchard,

${ }^{217} \mathrm{O}$ reitor Ladeuze indicou Planchard a instância do governo de Salazar (Revista Portuguesa de Pedagogia, IX, 1975, Coimbra, FLUC, IV). Lovaina era um dos centros católicos de filosofia e psicologia, sob a influência do cardeal Mercier e da Revue Neo-Scholastique que fundou, depois dirigida pelo medievalista Maurice de Wulf - $c f$. JoÃo AmEal, «Vitória do Tomismo», Nação Portuguesa, VI, (1931) 149.

${ }^{218}$ A Psicologia em Coimbra perderia os laços com a escola de Genebra e ficaria atada a Lovaina, cuja linha de investigação conduzida por Michotte criou uma tradição que, com Joseph Nuttin, se prolongaria - J. FERreira Marques, «Nuttin, Fraisse e a Psicologia em Portugal», Psychologica, (2004), 53-58; e id. «Perspectivas internacionales en la historia de la Psicologia en Portugal», Revista de Psicologia General y Aplicada, LIII (4º , 2000), 599-606. 
mestre equilibrado com a estranha (estrangeira, ao tempo) forma cordata e tolerante de encarar a vida, reconhece que em 1937 "chegava por mar a Portugal, com destino final em Coimbra, um jovem professor belga enviado pelo Reitor da Universidade de Lovaina que respondia a uma solicitação do governo português que procurava um especialista em ciências da educação, de preferência doutorado pela universidade católica belga, para ensinar em Coimbra. Este docente era eu". O relato prossegue, "depois de uma rápida volta pela velha e pitoresca cidade, o Director da Faculdade pediu ao motorista para me levar a casa do Dr. Joaquim de Carvalho que morava, naquela altura, na Rua da Ilha, próximo da Universidade onde ensinava, além das cadeiras de filosofia, a história da educação destinada, em princípio, aos professores do ensino secundário e aos médicos escolares do qual era director. Teria eu próprio de me encarregar de Psicologia escolar, de Pedagogia e de Didáctica gerais". Estranho é Planchard não relacionar, à época em que redige o relato (no final da vida), a sua vinda com a expulsão do ensino do especialista português.

O depoimento torna-se então confuso e inexacto, ao afirmar: "Isso foi o meu contacto inicial com a célebre e medieval universidade lusitana e o primeiro docente (além do poeta-director e de um docente que viria a ser um dos meus melhores amigos e colegas, o Dr. Sílvio Lima casualmente presente na residência do Prof. Carvalho, do qual era então assistente". O caso agrava-se: note-se, no documento original, que o parêntesis aberto não foi fechado nem a frase acabou. $\mathrm{O}$ redactor intercalou a frase na sobrelinha "do qual era então" mas com rasura. E, em termos factuais, em inícios de 37 não é já Lima assistente de Joaquim de Carvalho, mas professor auxiliar expulso e impedido de leccionar. É provável ter sido tratado como discípulo pelo mestre mas é irrazoável que Planchard não soubesse, não se apercebesse da situação de exclusão e vexame que ao colega português era imposta. É sensato pensar, com possibilidade fundante, que não estaria casualmente em casa de Carvalho, quando o professor belga aí chega guiado pelo poeta-director ${ }^{219}$. Boas razões há para supor, com o beneplácito de Eugénio de Castro, cujo perfil, obra e sensibilidade estética o figueirense

${ }^{219}$ BPMPFT-FF, Espólio Joaquim de Carvalho, Cx. PES - 31.2. 
admirava $^{220}$, que Planchard fosse ali informado do processo anómalo da expulsão de Sílvio Lima.

Bem o sabia a corporação. E se dúvidas houvesse sobre verosímeis causas do ataque intelectual e profissional, a prova inequívoca acha-se nos ficheiros do arquivo da PIDE. Após mais de vinte anos, o director informava o ministro da Educação sobre o exacto móbil que conduzira em 1935 à expulsão de Sílvio Lima: "parece não ter sido estranha a essa resolução a publicação de um livro de crítica a Sua Eminência o Cardeal Patriarca de Lisboa Doutor Manuel Gonçalves Cerejeira, livro esse que foi proibido e retirado de venda, pelos baixos instintos que revelava, por parte do autor, e impúdicas invencionices e falsidades com que pretendia denegrir tão venerando dignitário da Igreja"221. Impõe-se concluir: o serviço de Deus fora decidido e executado pelo governo e funcionários civis do Estado.

Desterrados da profissão os protestantes de 1935 afrontaram, por diversos modos, o alicerce ditatorial. Hereges, foram julgados e condenados - sem processo instrutório, defesa ou recurso -, pelo sacerdote dos funcionários, Pontífice da Nação e, no caso de Sílvio Lima (genuíno mestre do espírito crítico, José Ferreira da Silva, Biblos, 1979), na conjugada omissão do Príncipe da Igreja. "Não se pode deixar de pensar num certo sadismo dos seus executores, apesar do seu misticismo manifesto", notou Barahona Fernandes ${ }^{222}$. Perto do corpus linguístico, a si mesmo Sílvio Lima incluía, irónico, no grupo semiótico dos inocentes, "pecadores universitários", simbolicamente degolados $^{223}$. Degola é deterioração semiótica da voz no instante anterior ou simultâneo da morte, que tenta justificar, porque se falou demais. Criminosos que assaltam a livre opinião pública e assassinos que a executam, na pacífica ilha dos inocentes em Oslo ou no caso do jornalista Pearl no vídeo internáutico, objectivam silenciar, pois sem voz os executados aterrorizam. Induzir o terror é a eficaz notícia do terrorismo em acto e exclusiva publicidade. Como se a gaiola fosse

${ }^{220}$ Cf. J. de Carvalho, $O C$, VIII, 139; P. Archer, «Cartas de António Sardinha para Eugénio de Castro (1905-1924)», Arquivo Coimbrão, XL, 2008, 19-21.

221 ANTT- Arquivo da PIDE/DGS - Processo n. ${ }^{\circ} 1540$ (1) NT 1224, $f .93$.

${ }^{222}$ Barahona Fernandes, «Revivendo um ensaio de Sílvio Lima..., art. e o. c., XII, nota 1.

${ }^{223}$ Sílvio LimA, «Carta aberta às universidades portuguesas», art. c. e $O C$, II, 1675. 
procurar o pássaro, no anexim de Kafka ${ }^{224}$ : na exclusão universitária (o ius exclusivae), ou na vida geral das espécies, atente-se na empiria do mundo, pássaros mal voam em gaiolas. Provavelmente é o alvo último da exclusão: anular o livre e incondicional voo, singular prova ontológica da existência humana.

${ }^{224}$ Franz KAFKA, Aforismos, Lisboa, Ulmeiro, 2001, § 16, 10. 